\title{
In Writing and in Sound
}

\section{The Dalāil al-Khayrāt in the Late Ottoman Empire}

\author{
Sabiha Göloğlu | ORCID: 0000-0002-0939-5251 \\ University of Vienna, Vienna, Austria \\ sabiha.goeloglu@univie.ac.at
}

\begin{abstract}
Copies of Dalāil al-Khayrāt (Proofs of Good Deeds) by the Moroccan Sufi saint Muhammad b. Sulaymān al-Jazūlī (d. 870/1465) were in high demand in the eighteenthand nineteenth-century Ottoman Empire. This required producing manuscripts in large numbers and, later, printing the text. These mostly lithographic copies and corpora of the Dalāil al-Khayrāt, when combined with references to biographical dictionaries, inheritance records, inventories, library catalogues, and endowment deeds, reveal a great deal of information about the public and private prevalence of the text, within and beyond the empire. The Daläil al-Khayrāt appealed to many individuals, from Ottoman sultans to royal women, and from madrasa students to members of the learned class. Its copies were endowed to mosques and libraries, held in different book collections of the Topkapi palace, and were available from booksellers. Be it silently or aloud, the Dalāil al-Khayrāt could be read in private homes and in mosques from Istanbul to Medina, a feature of pious soundscapes across the empire.
\end{abstract}

\section{Keywords}

Muhammad b. Sulayman al-Jazuli - devotional texts - codicology - endowments recitation - soundscape 
The numerous copies of the Dalāil al-Khayrāt (Proofs of Good Deeds) and various references to it in written sources, attest to the popularity of this devotional text in the eighteenth- and nineteenth-century Ottoman Empire. ${ }^{2}$ Biographical dictionaries, inheritance records, inventories, library catalogues, and endowment deeds reveal a great deal about the public and private prevalence of the Daläil al-Khayrāt, including its presence in the soundscapes (sonic environment) of several major Ottoman cities. ${ }^{3}$ The brisk market for this collection of prayer blessings (șalā, pl. șalawāt) for the Prophet Muhammad is no surprise, as the text appealed to many individuals, from Ottoman sultans to royal women, and from madrasa students to members of the learned class. Daläil al-Khayrät copies were endowed to mosques and libraries, held in different book collections of the Topkapi palace, and were available at booksellers. Be it silently or aloud, in its entirety or in sections, the Daläil al-Khayrät was read in private homes and in mosques from Istanbul to Medina. Most Ottoman copies of the

1 Submitted in an earlier version on 4 July 2020. Accepted for publication 18 May 2021.

This article arose from a paper I presented at the workshop "From West Africa to Southeast Asia: The History of Muhammad al-Jazuli's Dala'il al-Khayrat Prayer Book (15th-2oth Centuries)" organized by Guy Burak and Deniz Beyazit at the Metropolitan Museum of Art in New York (17-18 May 2019). I would like to thank them as well as Lauren Nicole Davis, İrvin Cemil Schick, Zeren Tanındı, and Nazlı Vatansever for their feedback on the different drafts of this paper.

2 The full title of the text is Daläil al-khayrāt wa-shawāriq al-anwār fì dhikr al-șalāt 'alā alnabi al-mukhtār (Proofs of Good Deeds and Brilliant Bursts of Light in the Remembrance of Blessings on the Chosen Prophet). For an English translation, see Al-Jazūlī, Guide to Happiness: A Manual of Prayer, trans. John B. Pearson (Oxford: Printed for private circulation, 1907). For a selection of publications on the Dalä'il al-Khayrāt, see Frederike-Wiebke Daub, Formen und Funktionen des Layouts in arabischen Manuskripten anhand von Abschriften reli-

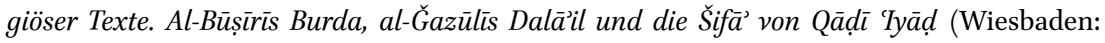
Harrassowitz Verlag, 2016); Nurul Iman Rusli, Heba Nayel Barakat, and Amira Salleh, eds., Dala'il al-Khayrat: Prayer Manuscripts from the 16th-19th Centuries (Kuala Lumpur: Islamic Arts Museum Malaysia, 2016); and Jan Just Witkam; Vroomheid en activisme in een islamitisch gebedenboek. De geschiedenis van de Dalāil al-Khayrāt van al-Ğazūlì (Leiden: Legatum Warnerianum, 2002). For a selection of dissertations on the prayer book, see Sabiha Göloğlu, "Depicting the Holy: Representations of Mecca, Medina, and Jerusalem in the Late Ottoman Empire" (PhD thesis, Koç University, 2018); Hiba Abid, "Les Dalāil al-Khayrāt d' al-Jazūlī (m. 869/1465). La tradition manuscrite d'un livre de prières soufi au Maghreb du xe/xvie au XIIIe/Xıxe siècles" (PhD thesis, École doctorale de l'École pratique des hautes études, Paris, 2017); and Semra Güler, “Türkiye Kütüphaneleri'ndeki Delāilü'l-Hayrātlar'da Minyatür” (PhD thesis, Uludağ University, 2017).

3 For a detailed definition of "soundscape," see R. Murray Schafer, The Soundscape: Our Sonic Environment and the Tuning of the World (Rochester, VT: Destiny Books, 1977), 4-5, 274-275. 
Dalāil al-Khayrāt were either arranged in eight sections (sing. hizb or hizip) or eight, four, three, and two parts that were differentiated with illuminated headings, section markers (hizip gülü), and/or marginal inscriptions that guided the reading of the text in eight days (from Monday to Monday) and in halves, thirds, and quarters. ${ }^{4}$

Archival documents present a wealth of information regarding the buying and selling of Dalāil al-Khayrāt manuscripts and prints, their presence in libraries and book collections, and the auditory functioning of the text in public spheres. Furthermore, certificates (sing. ijazza or icāzet), dedicatory inscriptions, marginal notes, ownership records, and seal impressions in Daläil al-Khayrāt copies unveil details about their endowers, institutions, owners, and users. ${ }^{5}$ Nevertheless, it is still difficult to assess how widely the Daläil alKhayrät was read in people's homes and to what extent it was understood, because its copies may have been kept for talismanic purposes and as prestigious items as well. ${ }^{6}$

Muhammad b. Sulaymān al-Jazūlī (d. 870/1465), the author of the Dalä̉il alKhayrāt, linked the "competing traditions of Shadhili and Qadiri Sufism" and his Jazuliyya order with the Moroccan concept of sainthood. ${ }^{7}$ The popularity

4 For the division into halves, thirds, and quarters in North African Dalāil al-Khayrāt copies, see Hiba Abid, "Material Images and Mental Ziyāra: Depicting the Prophet's Grave in North African Devotional Books (Dalāil al-Khayrāt)," Journal of Material Cultures in the Muslim World 1 (2020): 331-354, 334.

5 For reading practices in the Ottoman Empire, see Elif Sezer, The Oral and the Written in Ottoman Literature: The Reader Notes on the Story of Firüzşāh (Istanbul: Libra, 2015); Tülün Değirmenci, "Bir Kitabı Kaç Kişi Okur? Osmanlı'da Okurlar ve Okuma Biçimleri Üzerine Bazı Gözlemler," Tarih ve Toplum. Yeni Yaklaşımlar 13 (2011): 7-43; Christoph K. Neumann, "Üç Tarz-ı Mütala. Yeniçă̆ Osmanlı Dünyası'nda Kitap Yazmak ve Okumak,” Tarih ve Toplum. Yeni Yaklaşımlar 1 (2005): 51-76; and Johann Strauss, "Who Read What in the Ottoman Empire (19th-2oth Centuries)?" Middle Eastern Literatures 6 (2003): 39-76.

6 For talismanic uses of the Dalāil al-Khayrāt, see Sabiha Göloğlu, "Linking, Printing, and Painting Sanctity and Protection: Representations of Mecca, Medina, and Jerusalem in Late Ottoman Illustrated Prayer Books," in The Ascension of the Prophet and the Stations of His Journey in the Ottoman Cultural Environment:The Miraj and the Three Sacred Cities of Islam in Literature, Music, and Illustrated Manuscripts, eds. Ayşe Taşkent and Nicole Kançal-Ferrari (Istanbul: Klasik Publications, forthcoming), 485-505; and Hiba Abid, "La vénération du Prophète en Occident musulman à travers l'étude codicologique de livres de piété (XIe/Xvire-XıIIe/ XIXe siècles)," Archives de sciences sociales des religions 178 (2017): 157-158.

7 Vincent J. Cornell, Realm of the Saint: Power and Authority in Moroccan Sufism (Austin, TX: University of Texas Press, 1998), 173-176, 285. See also Yehoshua Frenkel, "Muhammad alDjazouli's Image in Biographical Dictionaries and Hagiographical Collections Written during Sa'did Period in Morocco," Maghreb Review 18 (1993): 18-33; Süleyman Uludağ, "Muhammed b. Süleyman Cezūlī," in Türkiye Diyanet Vakfı İslām Ansiklopedisi (Istanbul: Türkiye Diyanet Vakfl, 1993), 7·515-516; and M. Ben Cheneb, "al-Djazūlī," in Encyclopaedia of Islam, eds. B. Lewis, Ch. Pellat, and J. Schacht, vol. 2 (Leiden: Brill, 1991), 527-528. 
of his prayer book soon extended beyond North Africa and spread to various parts of the Islamic world, as a commonly consulted work for reciting prayer blessings for the Prophet (tașliya). ${ }^{8}$ From the second half of the eighteenth century onwards, the Shādhiliyya order gained popularity in Istanbul and had up to three zawiyas, ${ }^{9}$ while the Qadiri order sustained a steady and widespread influence, also in the Balkans and Anatolia. ${ }^{10}$ The Dalä'il al-Khayrāt was not only copied and read among these Sufi orders, but also others, such as the Naqshbandiyya and the Mawlawiyya. ${ }^{11}$ Moreover, the written and sonic formats of

8 For devotional practices regarding the Prophet Muhammad, see Christiane Gruber, The Praiseworthy One: The Prophet Muhammad in Islamic Texts and Images (Bloomington, IN: Indiana University Press, 2019); and Annemarie Schimmel, And Muhammad Is His Messenger: The Veneration of the Prophet in Islamic Piety (Chapel Hill, NC: University of North Carolina Press, 1985).

9 On the Shadhili order, see Ahmet Murat Özel, "Şāzelī" and "Şāzeliyye," Türkiye Diyanet Vakfı İslām Ansiklopedisi vol. 38 (Istanbul: Türkiye Diyanet Vakfi, 2010), 385-387 and 387-39o; M. Baha Tanman, "Şazelī Tekkesi" and "Şazelilik," Dünden Bugüne İstanbul Ansiklopedisi, vol. 7 (Istanbul: Türkiye Ekonomik ve Toplumsal Tarih Vakfi, 1994), 138-139 and 139-140; and Ömer Tuğrul İnançer, "Şazelīlik:Zikir Usulü ve Musiki," Dünden Bugüne İstanbul Ansiklopedisi, vol. 7 (Istanbul: Türkiye Ekonomik ve Toplumsal Tarih Vakfi, 1994), 140-141.

10 The Dalāil al-Khayrāt and the Hizb 'Abd al-Qädir al-Gülānì of the founder of the Qãdiriyya order (d. 561/1166) may be found in the same prayer miscellanies. For instance, see the composite manuscript in the Kubbealtı Foundation Ekrem Hakkı Ayverdi Collection (EHA VII/4), in which the Daläil al-Khayrāt was compiled with the al-Hizb al-Azam, Hizb al-Baḥr, Hizb al-Nawawī, Hizb 'Abd al-Qādir al-Gïlānì and Hizb al-Nașr. Şebnem Eryavuz, Orhan Sakin, Sabiha Göloğlu, and Gülnur Duran, Catalogue of the Manuscripts in the Collection of the Kubbealtı Foundation, trans. İrvin Cemil Schick (Istanbul: Kubbealtı Akademisi Kültür ve Sanat Vakfi, 2021), 240-243, cat. 87; and M. Baha Tanman, ed., Ekrem Hakkı Ayverdi 1899-1984. Mimarlık Tarihçisi, Restoratör, Koleksiyoner (Istanbul: İstanbul Araştırmaları Enstitüsü, 2014), 202-203, cat. 85. A Dalāil al-Khayrāt copy (sнм Küt. 611) in the Sadberk Hanım Museum in Istanbul ends with prayers for al-Jazūlī and the shaykhs of the Qādiriyya order. Zeren Tanındı, Harmony of Line and Colour: Illuminated Manuscripts, Documents, and Calligraphy in the Sadberk Hanım Museum Collection, vol. 1 (Istanbul, Sadberk Hanım Museum, 2019), 242-243, cat. 53.

11 Several copyists of the Dalāil al-Khayrāt carry the titles of "Mevlevi" and "Nakşibendi" and several prayer books including the Daläil al-Khayrät have contents related to these orders. For instance, a composite manuscript of Qur'ānic excerpts, the Daläil al-Khayrāt, and Mawlawi litanies (awräd) can be found in the Konya Mevlana Museum (Müze 45). Serpil Bağcı, Konya Mevlānā Müzesi Resimli Elyazmaları (Konya: Konya ve Mülhakatı Eski Eserleri Sevenler Derneği, 2003), 32-35, cat. I.7. Furthermore, a composite manuscript of Qurānic excerpts, the Dalāil al-Khayrāt, and Naqshibandi litanies with a Naqshbandi certificate can be found in the Berlin State Library (Hs. or. 14194, dated $1808 \mathrm{CE}$ ). "Hs. or. 14194," Staatsbibliothek zu Berlin, Preußischer Kulturbesitz, Digitalisierte Sammlungen. Available at: http://resolver.staatsbibliothek-berlin.de/SBBooooE8oAooo1oooo last accessed 22 November 2020. 
this devotional text reached an even larger public based on book and recitation endowments by royal women, the learned, and wealthy individuals to libraries, madrasas, and mosques.

In the late Ottoman Empire, the Daläil al-Khayrāt was frequently referred to as "Delāill" and "Delāill-i Şerîf" and compiled with other devotional texts. Among these are the En'âm-ı Şerīf, ${ }^{12}$ including a selection of Qurānic excerpts (such as Sürat al-An'ām [Qur'ān 6] or "the Cattle," which gives the book its name), religious imagery, and/or prayers (ad'iya); ${ }^{13}$ the Asmä Așhāb Badr (the names of the Prophet's companions who fought in the Battle of Badr); alJazūlì's Hizb al-Faläh (Litany of Salvation); the Hanafì scholar and calligrapher 'Alī al-Qāri’s (d. 1014/16o5) al-Hizb al-Aźzam (The Greatest Litany); the Moroccan scholar and founder of the Shādhiliyya order Abū al-Ḥasan al-Shādhilī's (d. 656/1258) Hizb al-Bahr (Litany of the Sea), Hizb al-Barr (Litany of the Land), al-Hizb al-Kabìr (The Great Litany), and Hizb al-Nașr (Litany of Victory); the Shāfi'ī scholar and jurist al-Imām al-Nawawīs (d. 676/1277) litanies (Hizb al-Nawawī ); and/or the Sufi poet of the Shādhiliyya order Sa'īd al-Būṣin̄ìs (d. 694-696/1294-1297) Qașidat al-Burda (Mantle Ode). ${ }^{14}$ Several miscellanies or composite manuscripts that bring together the Daläil al-Khayrāt with one or more of these texts exist in collections today and are mentioned in historical sources.

Muḥammad al-Mahdī al-Fāsī’s (d. 1109/1698) Arabic commentary Mațāli‘alMasarrāt (Points of Ascents of Lucky Stars) and Karadavudzade's (d. 1170/1756) Turkish commentary Tevfiku Muvaffikil-Hayrāt (Guidance of Success of Good Deeds) were among the widely available exegeses of the text in the Ottoman

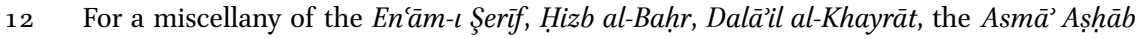
$B a d r$, and the Qașidat al-Burda copied by Mehmed b. Ali Zügrevi of Ankara (a disciple of Seyyid Mehmed Nuri) dated to $1175 / 1761-1762$, see Or. 7259 in the British Library, London. Alexander George Ellis and Edward Edwards, A Descriptive List of the Arabic Manuscripts Acquired by the Trustees of the British Museum since 1894 (London: British Museum, 1912), 16,59 .

13 For the En'äm-ı Şerîf, see Christiane Gruber, "A Pious-Cure All: The Ottoman Illustrated Prayer Manual in the Lilly Library," in The Islamic Manuscript Tradition: Ten Centuries of Book Arts in Indiana University Collections, ed. Christiane Gruber (Bloomington, IN: Indiana University Press, 2009), 117-153; and Alexandra Bain, "The En`am-ı Şerif: Sacred Text and Images in a Late Ottoman Prayer Book," Archivum Ottomanicum 19 (2001): 213-238. See also the detailed catalogue description of an En'ām-ı Şerîf copy (MS 1995-014) in Jan Just Witkam, "The Islamic Manuscripts in the McPherson Library, University of Victoria, Victoria, B.C.," Journal of Islamic Manuscripts 1 (2010): 108-133.

14 For al-Būṣîni’s Qașidat al-Burda and other mantle odes, see Suzanne Pinckney Stetkevych, The Mantle Odes: Arabic Praise Poems to the Prophet Muhammad (Bloomington, IN: Indiana University Press, 2010). 
lands, even though other commentaries were also copied. ${ }^{15}$ Commentaries of the Daläil al-Khayrāt were frequently mentioned in library catalogues and inheritance records, which, to a certain extent, reflect the contemporary efforts to study and comprehend the text. This article, however, does not attempt to understand this devotional text in terms of its meanings, but rather it explores the material values of its written forms, the auditory significance of its recitations, and its prominent presence in the public and private spheres. Using archival sources and codicological analysis, it aims to contextualize how the Dalāil al-Khayrāt was integral to charitable, commercial, and devotional activities in the eighteenth-and nineteenth-century Ottoman Empire. The following sections suggest various tracks for approaching the production, ownership, circulation, endowment, and recitation of the Daläil al-Khayrät, which can be expanded and elaborated in future studies.

An intensive production and widespread circulation of prayer books existed in the late Ottoman Empire, as the manuscripts of the Daläil al-Khayrāt and written sources demonstrate. Biographical dictionaries record several calligraphers who copied the Daläil al-Khayrät, in addition to the Qur'ān, and the "En'ām" (the prayer book or only the süra). In Devhatü'l-Küttāb (Tree of Scribes, 1150/1737-1738) and Tuhfe-i Hatțățīn (Gift of Calligraphers, 1173/1759-176o), Suyolcuzade Mehmed Necib (d. 1171/1758) and Müstakimzade Süleyman Sadeddin (d. 1202/1788) attributed varying quantities of Daläil al-Khayrāt copies to eighteenth-century Ottoman calligraphers. ${ }^{16}$ Suyolcuzade and Müstakimzade

15 Among the other Turkish commentaries were İbrahim b. Salih el-Kıbrısi's VesāillülHasenāt (Occasions of Good Deeds) and Mehmed Şakir ibn Sunullah el-Ankaravi's ŞerḥülDela'il (Commentary of the Dala'il). Guy Burak, "Prayers, Commentaries, and the Edification of the Ottoman Supplicant," in Tijana Krstić and Derin Terzioğlu (eds.), Historicising Sunni Islam in the Ottoman Empire c. 1450-c. $175^{\circ}$ (Leiden: Brill, 2020); 241-246; Guy Burak, "Collating the Signs of Benevolent Deeds: Muhammad Mahdī al-Fāsì’s Commentary on Muḥammad al-Jazūlī's Daläil al-Khayrāt and Its Ottoman Readers," Philological Encounters 4 (2019): 135-157; and Hatice Kelpetin Arpaguş, "Kara Dāvud," in Türkiye Diyanet Vakfı İslām Ansiklopedisi, vol. 24 (Istanbul: Türkiye Diyanet Vakfı, 20o1), 359.

16 Suyolcuzade noted that Ahmed Efendi, Hüseyin Beşe b. Ahmed, Hatibzade Mehmed Efendi, Eğrikapılı Mehmed Rasim, Attarzade Hüseyin Efendi, Osman Efendi, Mustafa Çelebi, Mollazade Mehmed Efendi, Mehmed Emin Efendi, and Yusuf Efendi were among the calligraphers who copied the Dalä̉il al-Khayrāt. Suyolcuzade Mehmed Necib, Devhatül-küttab, ed. Kilisli Muallim Rifat (Istanbul: Güzel Sanatlar Akademisi Neşriyatı, 1942), 13, 
noted several calligraphers who had copied one to three hundred or numerous (müte'addid) Dalāill al-Khayrāt manuscripts. In Son Hattatlar (Last Calligraphers, 1955), İbnülemin Mahmud Kemal İnal mentions several nineteenthand early-twentieth-century calligraphers who had produced copies of the Daläil al-Khayrāt, attesting to the widespread production and popularity of this prayer book. ${ }^{17}$

Other calligraphers and copyists were also responsible for the dissemination of the Daläil al-Khayrāt. However, not all of them were recorded in biographical dictionaries. Two Daläil manuscripts copied by el-Hacc Ahmed Hanbeli II, held in the Beyazıt Library (Veliyyüddin $5^{6} 7$ and 568 ), also exemplify the intensive copying of the prayer book. In their colophons, the calligrapher noted that these manuscripts were the fourth and fifth of multiple copies by his hand. Moreover, there are other corpora of the Daläil al-Khayrāt that might have a single copyist or multiple ones. For instance, two series of five manuscripts [figure 1, figure 2], which have similar bindings, illumination, and paintings, have been preserved in the İnebey Manuscript Library in Bursa (HO 1223-1227) and the Topkapi Palace Museum Library in Istanbul (EH 1033-1037).

The İnebey manuscripts were formerly kept in the library of the Haraççıŏlu Madrasa in Bursa and inscribed with several scribbles and șalawāt on their flyleaves. All five manuscripts of this corpus measure around $28.4 \times 18.5 \mathrm{~cm}$ and have gold rulings and eleven lines. They feature maroon leather bindings with flaps and medallions. These manuscripts open with rectangular headpieces illuminated only with gold. The İnebey corpus displays single or half-page compositions of the minbar and the tombs of the Prophet Muhammad, Abū Bakr, and 'Umar drawn simply in black ink and gold [figure 1]. Only one of them (HO 1224) has a colophon that provides the completion date of 1166/1752-1753 and gives the name of the calligrapher as Ahmed Uşaki, a disciple of es-Seyyid Mehmed Bursevi.

40, 46, 52-53, 9o, 98, 123, 125, 130, 145. Müstakimzade noted that Şeyh İbrahim b. Mehmed, İsmail Yesarizade, Şemseddin b. Süleyman, Mehmed b. es-Seyyid Mehmed b. Abdurrahman, Eğrikapılı Mehmed Rasim, and es-Seyyid Osman Eyyubi were among the calligraphers who copied the Dalầil al-Khayrāt. Müstakimzade, Tuhfe-i Hattātīn, ed. Mustafa Koç (Istanbul: Klasik, 2014), 41, 110, 211, 381, 422, 621.

17 İbnülemin Mahmud Kemal İnal noted that Abdülkadir Şükri Efendi, Mehmed Arif Bey, Ahmed Arif Efendi, Mustafa İzzet Efendi, Kayışzade Osman Nuri Efendi, Osman Nuri Efendi, Osman Efendi, Ahmed Rakım Efendi, Mehmed Şevki Efendi, Mehmed Vasfi Efendi, and İbrahim Hakkı Efendi were among the calligraphers who copied the Dalāil alKhayrāt. İbnülemin Mahmud Kemal İnal, Son Hattatlar (Istanbul: Maarif Basımevi, 1955), $29,52,56,16$ o, 252-253, 257, 286, 401, 447, 555 . 


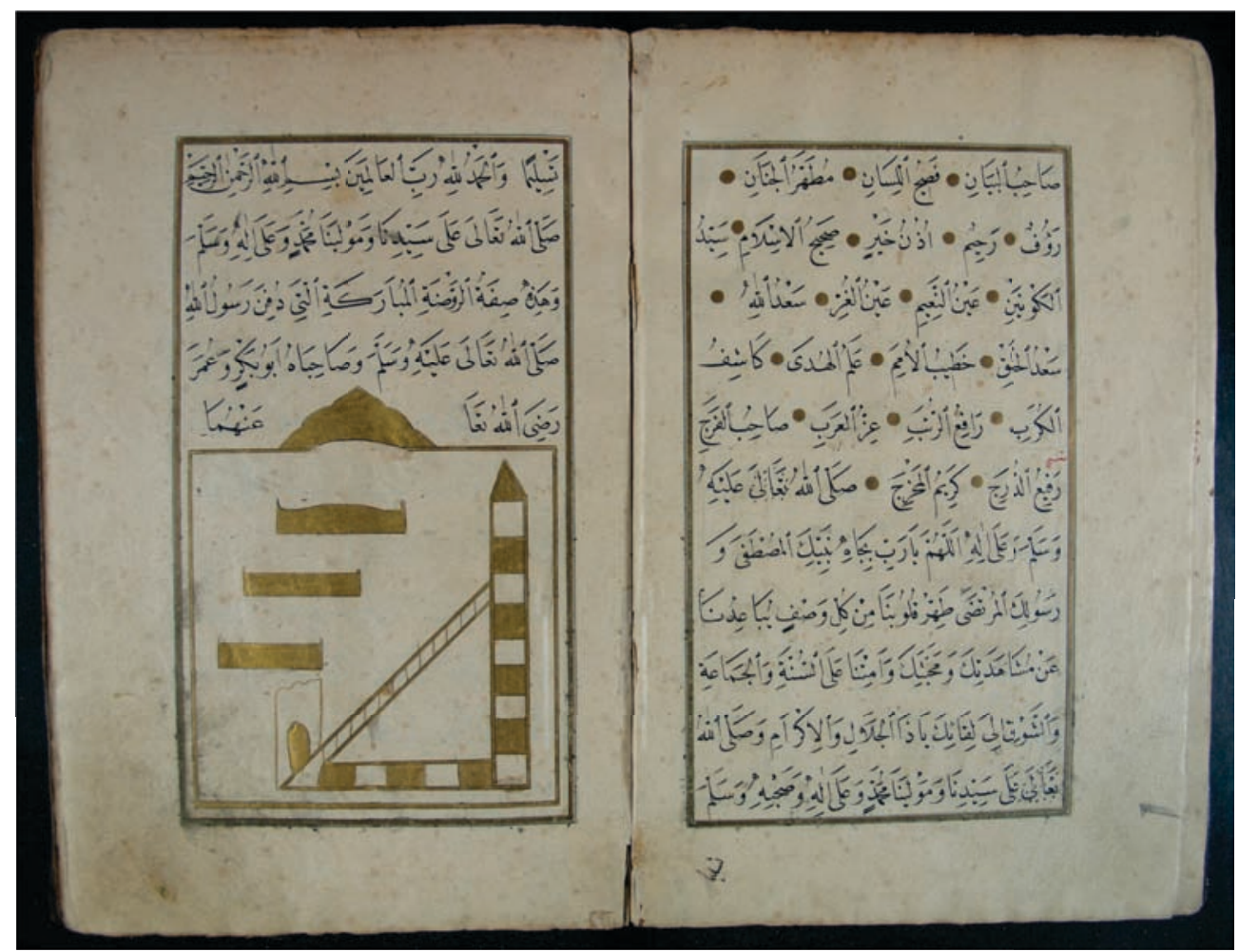

FIgURE 1 Minbar and Tombs of the Prophet Muhammad, Abū Bakr, and 'Umar. BURSA INEBEY LIBRARY, HO 1223, FOLS. 1OB-11A

The Topkapi corpus reveals more information about the identities of its calligraphers. All five manuscripts are signed by different hands: Berber Mehmed (of serāy-i 'atīk, EH 1033); İsmail Şükri (EH 1034); Mehmed Şehri (kethüdā-i ġlmān-i serāy-i 'atīk, EH 1035); Mehmed Tavil (EH 1036); and Derviş Mehmed (EH 1037). ${ }^{18}$ EH 1035 and EH 1037 were completed in 1176/1762-1763, whereas the other three remain undated. EH 1036 measures $13 \times 8.5 \mathrm{~cm}$ and has gold rulings, while the remaining four roughly measure $15 \times 10 \mathrm{~cm}$ and have red rulings. There is no consistency in the number of lines among the copies, as they change between nine, eleven, and thirteen. All five manuscripts have maroon leather bindings with flaps and gilded medallions, pendants, and borders.

18 Fehmi E. Karatay, Topkapı Sarayı Müzesi Kütüphanesi Arapça Yazmalar Kataloğu, vol. 3 (Istanbul: Topkapı Sarayı Müzesi, 1966), 269-27o, cat. 5492-5496. 


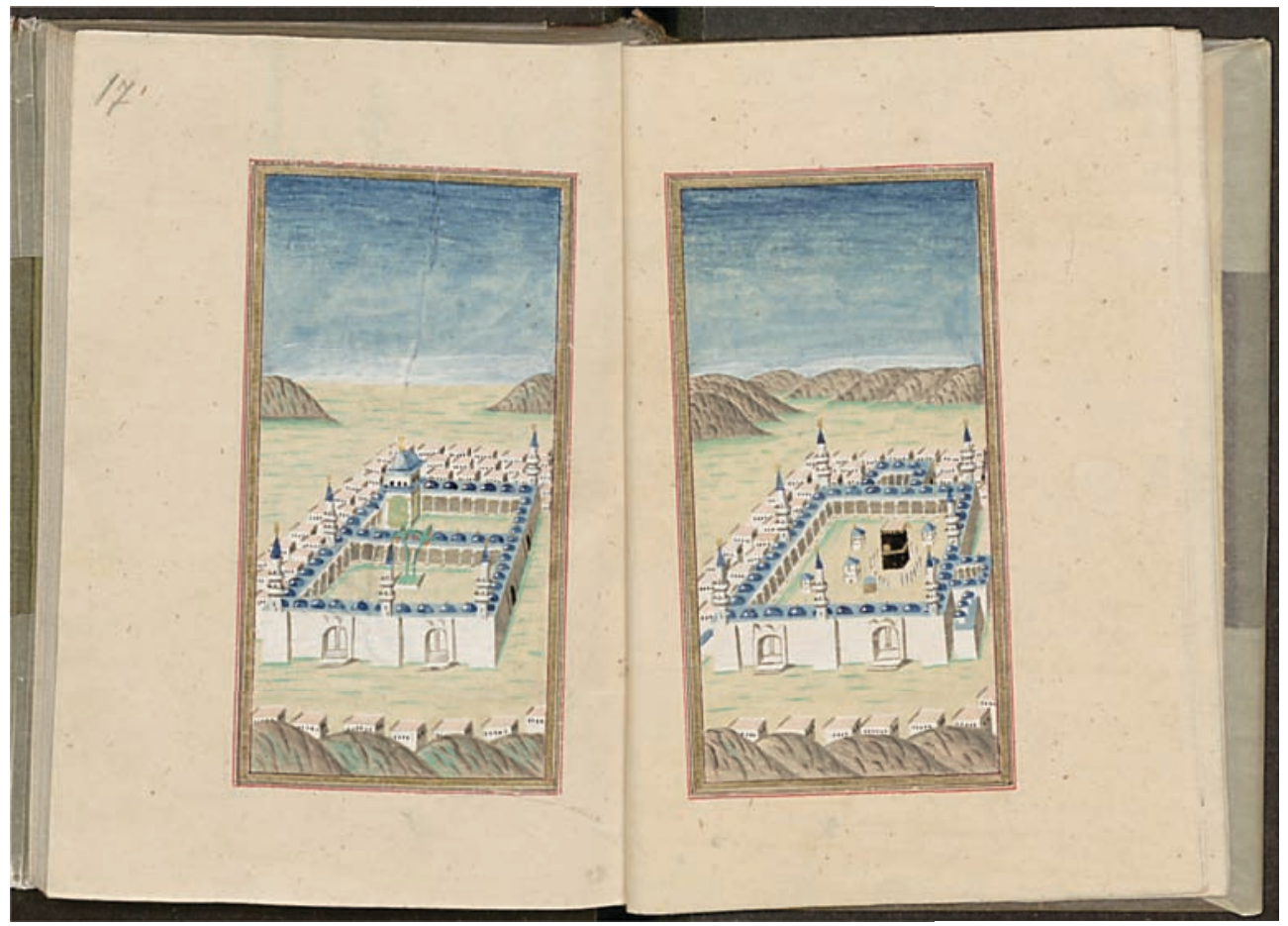

FIGURE 2 Mecca and Medina. Dalā'il al-Khayrāt, ca. 1762, copyist: Berber Mehmed (of serāa-i 'atīk), $15 \cdot 3 \times 10.3 \mathrm{~cm}, 104$ folios, 11 lines

TOPKAPI PALACE MUSEUM LIBRARY, EH 1033, FOLS. 16B-17A

They open with similar illuminated headpieces consisting of small green flowers and red and blue finials. The perspectival views of Mecca and Medina in the Topkapi corpus seem to be all by the same hand and from the same specimen [figure 2]. Their layouts and colouring are almost identical; however, they display small variations in the urban fabric and the perspectival cone of vision.

The İnebey and Topkapi corpora [figures 1 and 2] and many others (e.g. three-manuscript-corpus that will be mentioned later, figure 6) confirm that the popularity of the Dalāil al-Khayrāt in public, educational, and palatial spheres necessitated the rapid production of its copies in various calibres. Although the same binder, illuminator, and painter (or a group of them) might have worked on all five manuscripts, the calligraphers showed variation within each corpus. The former corpus seems to have been copied by at least three different calligraphers, while the copying of the text in the latter corpus was performed by five calligraphers, two of whom were clearly associated with the old palace (serāy-i 'atīk). 
Archival sources also provide insights into the production of manuscripts, as well as their costs. A private notebook of expenditures kept by a wealthy Istanbul resident lists the costs of a Qur'ān and a Daläil al-Khayrāt copy that was paid for in instalments between $1247 / 1832$ and $1251 / 1835$ [figure 3]. ${ }^{19}$ The costs of paper (kāgad), copying/writing (tahrīr), and illumination (tezhīb) were recorded with the additional costs of corrections and writing of hilye and chapter titles (tașhịh ve hilye-i şerîfe ve ser-i süre tahrīiri) for the Quräan copy and the writing of glosses (kenār tahrīri) for the Daläil al-Khayrāt copy. ${ }^{20}$ For these manuscript commissions, Sükuti İbrahim Efendi (d. 1834) was responsible for the copying, whereas Mücellid (binder) Ahmed Efendi was given the task of illumination (there is no specific amount listed for binding). ${ }^{21}$ The total costs were 5,300 guruş for the mușhaf (2,00o ġuruş for copying, 3,00o guruş for illumination, and 300 guruş for other costs) and 1,89o guruş for the Daläil al-Khayrāt copy (640 guruş for copying and 1250 guruş for illumination), in

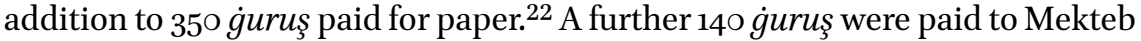
Hocası (school teacher) İbrahim Efendi and Mücellid Ahmed Efendi for two or more al-Dawr al-Ā'ā (also known as Hizb al-Wiqāya) of Muhyī al-Dīn Ibn al'Arabī (d. 1240). ${ }^{23}$ Even though al-Dawr al-Ā'lā was commonly compiled with the Daläil al-Khayrät, it is not clear whether in this case the two texts were compiled together or produced as separate manuscripts.

Similarly, another document notes the expenses of a Daläil al-Khayrāt manuscript commissioned by Refia Sultan (d. 188o), a daughter of Sultan Abdülme-

19 For an analysis of this notebook, see Faruk Doğan, "Sahibi Bilinmeyen Hususi Bir Masraf Defterinin Osmanlı Sosyal ve İktisat Tarihi Açısından Kullanılabilirliğine Dair Bir Deneme," Türk Dünyası Incelemeleri Dergisi 18 (2018): 355-376.

$20 \quad$ The Republic of Turkey's Presidency State Archives, D.M.d, 37228, p. 2.

21 For an entry about Sükuti İbrahim Efendi, see İnal, Son Hattatlar, 143. For a mușhaf copied by the same calligrapher and dated to $1247 / 1831$, see A 1663 in the Istanbul University Library. Doğan, "Sahibi Bilinmeyen Hususi Bir Masraf Defterinin Osmanlı Sosyal ve İktisat Tarihi Açısından Kullanılabilirliğine Dair Bir Deneme," 362. For a Dalāil al-Khayrāt manuscript copied by the same calligrapher and dated to $1245 / 1829-183$, see A $55^{8}$ in the Istanbul University Library.

22 Doğan's calculation of the costs for the Qurān copy is slightly higher than the one provided here, due to the inclusion of paper and al-Dawr al-ÁA $\bar{l}$ costs in the total sum. Doğan, "Sahibi Bilinmeyen Hususi Bir Masraf Defterinin Osmanlı Sosyal ve İktisat Tarihi Açısından Kullanılabilirliğine Dair Bir Deneme," $361-363$.

23 For a critical edition of Muhyī al-Dīn Ibn al-'Arabī's al-Dawr al-Alā, see Suha Taji-Farouki (ed.), Muhyiddin Ibn Arabi. A Prayer for Spiritual Elevation and Protection: Al-Dawr al-a $\overline{l a}^{a}$ (Hizb al-wiqāya). Study, Translation, Transliteration and Arabic Text (Oxford: Anqa Publishing, 2006). 


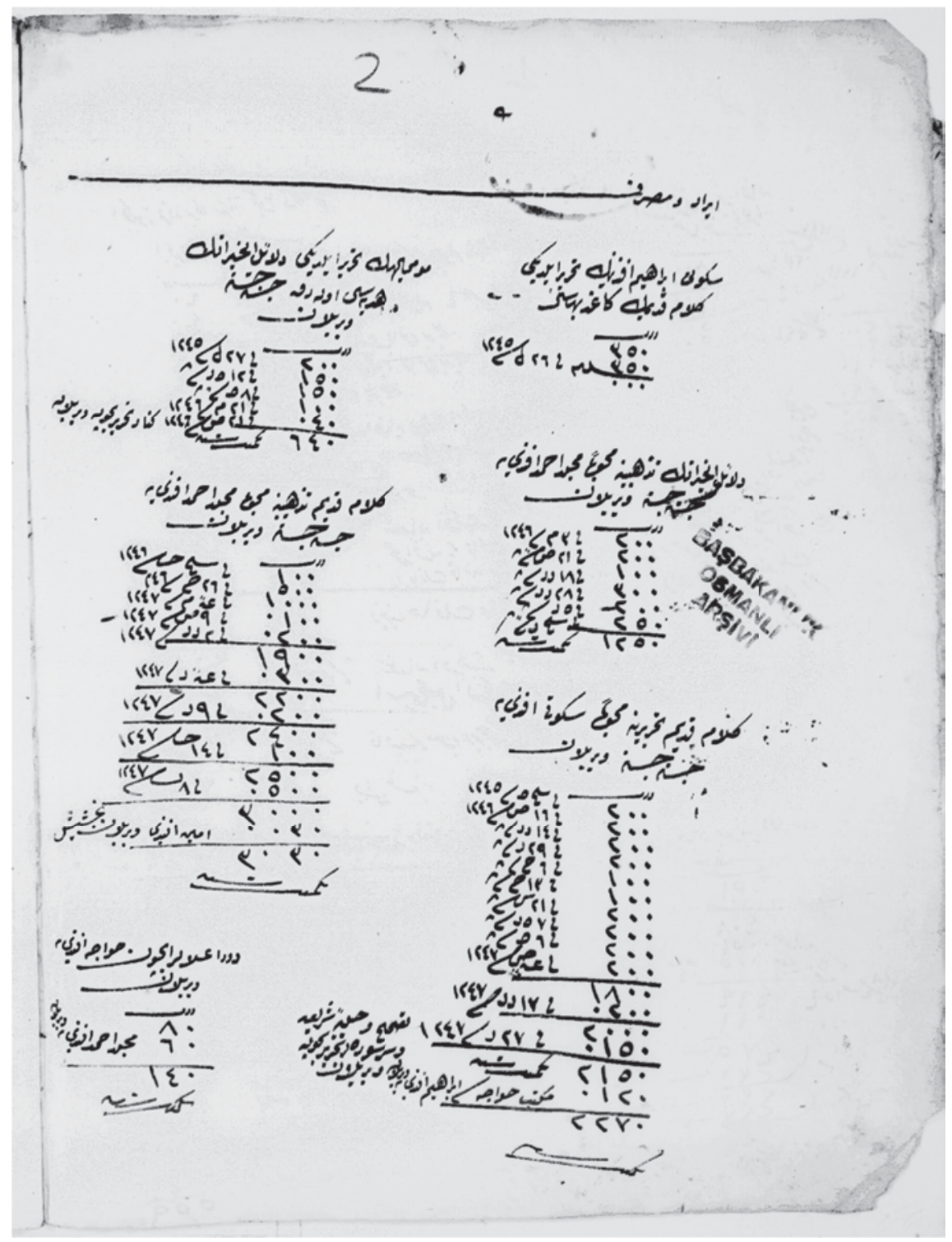

FIGURE 3 Production costs of a Qur'ān and a Dalä'il al-Khayrāt copy paid for in instalments between 13 Şaban 1247/17 January 1832 and 4 Muharrem 1251/2 May 1835 THE REPUBLIC OF TURKEY'S PRESIDENCY STATE ARCHIVES, D.M.D, 37228, P. 2 
cid (r. 1839-1861) and Gülcemal Kadınefendi (d. 1851).24 This is a receipt signed by the calligrapher Mehmed Şevket, confirming payments of 1,500 guruş for the copying (ücreti tahrïriyye) and $224 \dot{g} u r u s ̧$ for paper (kägad parası). ${ }^{25}$ There is a lavishly illuminated Dalāil al-Khayrāt copy signed by Mehmed Şevket (d. 18771878), a disciple of es-Seyyid Ahmed Rakım, in the Istanbul University Library (A 5721). This manuscript is written in naskh and thuluth scripts and dated to 1290/1873-1874. ${ }^{26}$ Its green leather binding with a large radiating star (yld $ı$ ) and smaller crescents, as well as the square seal impressions of the Ylldız Palace Library, makes this prayer book a possible match for the one ordered by Refia Sultan.

Here, it is important to point out that the prices for paper and copying were differentiated in both documents, Mehmed Şevket charged around 30 per cent more for copying the Daläil al-Khayrāt than Sükuti İbrahim Efendi did for a wealthier and more prestigious patron; the illumination was the costliest task in the earlier manuscript, and the binding and illumination of the later manuscript were commissioned separately. In the light of more documents regarding the costs and commissioners of manuscripts, it would be possible to have a more nuanced understanding of the Daläil al-Khayrät's production in the Ottoman lands. In addition to such commissioned manuscripts, those produced for the speculative market can also deepen our knowledge about devotional books.

\section{Inheritance Records, Market, and Ownership}

Inheritance records (tereke or muhallefāt) provide valuable information about the market for prayer books, as well as their private ownership and circulation. These documents exist in court registers (şeriyye sicilleri) and list deceased men's and women's assets, sold on the request of heirs and claimants, with their

24 For a short entry on Refia Sultan, see Necdet Sakaoğlu, Bu Mülkün Kadın Sultanları. Valide Sultanlar, Hatunlar, Hasekiler, Kadınefendiler, Sultanefendiler (Istanbul: Alfa Tarih, 2015), 613-618; and M. Çağatay Uluçay, Padişahların Kadınları ve Kızları (Ankara: Türk Tarih Kurumu Basımevi, 1980), 153-154. For an alphabet book (elif-ba cüzü) that belonged to Refia Sultan, see Çağlarboyu Anadolu'da Kadın. Anadolu'da Kadının gooo Yılı (Istanbul: T.C. Kültür Bakanlığı, 1993), 211, cat. C 14 .

25 The Republic of Turkey's Presidency State Archives, TS. MA.e 9-17. See also Ali Akyldız, Refia Sultan. Mümin ve Müsrif Bir Padişah Kızı (Istanbul: Tarih Vakfı Yurt Yayınları, 1998), 14-15.

26 For a short entry on Mehmed Şevket, see İnal, Son Hattatlar, 405-406. 
titles and values. ${ }^{27}$ İsmail Erünsal presents valuable research about the buying and selling of books in the Ottoman Empire based on such records. He demonstrates that several devotional books appeared in the inheritance records of booksellers and merchants along with other objects, such as calligraphic panels (sing. levha), schematic and calligraphic descriptions of the Prophet's physical characteristics (sing. hilye), and qibla compasses (sing. kıblenümā) ${ }^{28}$ Booksellers and merchants sold manuscripts as finished objects and texts blocks, which could have been bound, illuminated, or illustrated upon the request of buyers. ${ }^{29}$ As one would expect, these recorded manuscripts could have been acquired as second hand or produced for the speculative market.

Dalāil al-Khayrāt manuscripts and prints frequently feature in price lists of the deceased's belongings, either separately or as part of a total sum for bundles. Erünsal notes that a printed copy of Karadavudzade's Turkish commentary on the Daläil al-Khayrät could sell for up to 16,80o akçe in the latenineteenth century, a manuscript copy of the Daläil al-Khayrāt by Yesarizade (İsmail or Mustafa İzzet) for 48,000 akçe in 1872 , a copy by Mustafa İzzet (Kadiasker or Yesarizade) for 311,040 akçe in 1887, and a copy by Şeyh Hamdullah for 16,200 akçe in $1910 .{ }^{30}$ In 1872, a Daläil al-Khayrāt by Çemşir Hafız Mehmed Salih Efendi (d. 1236/1820) was sold for 96,ooo akçe, whereas a Qur'ān copy by the same calligrapher was sold for 840,000 akçe. ${ }^{31}$ In 1879 , the daily

27 Tahsin Özcan, "Muhallefāt," in Türkiye Diyanet Vakfi İslām Ansiklopedisi, vol. 30 (Istanbul: Türkiye Diyanet Vakfi, 2005), 406-407.

28 İsmail E. Erünsal, Osmanlılarda Sahaflık ve Sahaflar (Istanbul: Timaş Yayınları, 2013), 131$132,163,169-170$.

29 Ibid., 131-132.

30 Erünsal, Osmanlılarda Sahaflı ve Sahaflar, 181, 192, 197. For the value of silver guruş (120 akçe) in the nineteenth century, see the table in Şevket Pamuk, Osmanlı Imparatorluğu'nda Paranın Tarihi (Istanbul: Tarih Vakfı Yurt Yayınları, 2012), 208. A miscellany of the Enām-ı Şerīf and the Daläil al-Khayrāt (1155/1742) and a copy of the Daläil al-Khayrāt (1171/17571758) by İsmail Yesarizade (d. 1765) are preserved in the Sakıp Sabancı Museum (103o359) and the Konya Mevlana Museum (İhtisas Kütüphanesi 5917). See "Dua Mecmuası," Sakıp Sabancı Müzesi Dijital Koleksiyonları ve Arşivleri. Available at https://digitalssm .org/digital/collection/Kitapvehat/id/193277/rec/2 last accessed 22 November 202O; and Bağcl, Konya Mevlānā Müzesi Resimli Elyazmaları, 20-21, cat. I.2. Yesarizade Mustafa İzzet (d. 1849) was a master of ta'līq calligraphy and the majority of Ottoman Daläil al-Khayrāt copies were written in naskh script. For a copy of the Daläil al-Khayrāt (1251/1835-1836) that Yesarizade Mustafa İzzet copied in ta lì $q$, see A 5559 in the Istanbul University Library. A copy of the Dalāil al-Khayrāt (1258/1842-1843) copied by Kadıasker Mustafa İzzet (d. 1876) and preserved in the Istanbul University Library (A 5557) will be subsequently mentioned.

31 Erünsal, Osmanlılarda Sahaflıve Sahaflar, 197. For the calligrapher, see İnal, Son Hattatlar, 352-353. 
wages of a common labourer (rençber) and a mason (duvarcı) in Istanbul were 958 and 1,704 akçe, respectively; thus, the purchase of one of these manuscripts would have cost the equivalent of one to several months of salary. ${ }^{32}$

Similarly, based on a selection of inheritance records, both M. Şükrü Hanioğlu and Henning Sievert provide a glimpse into book collections of the Ottoman ruling class (askerī). According to Hanioğlu's statistics from 1164/1750-1751 and 1215/1800-1801 (44 members of the ruling class from each year), Daläil al-Khayrät was among the most common religious books (10 and 15 copies in the respective years) owned by the elite after copies of the Qur'ān (mușhaf, pl. mașāhif ), the Ḥanafi jurist Ibrāhīm al-Ḥalabī's (d. 1549) Multaqā al-Abhur (Confluence of the Seas), and Birgivi Mehmed Efendi's (d. 1573) catechism ('ilm$i$ hạal) Vasiyyet-i Birgivi (or Vasiyetnāme, the Testament). ${ }^{33}$

Sievert's analysis of eighteenth-century records reveals that after Qur'ān copies, Qāḍī 'Iyāḍ̂s's (d. 544/1149) Kitāb al-Shifä’, the "En'ām" (the prayer book or only the süra), the Daläil al-Khayrāt, and commentaries on the latter were commonly owned manuscripts. ${ }^{34}$ In one of Bahir Mustafa Paşa's (a disgraced grand vizier) inheritance records from 1765, a copy of Muhammad al-Mahdī al-Fāsì's commentary on the Daläil al-Khayrāt was sold for 4,80o akçe, two Daläil al-Khayrāt copies were sold for 6,ooo and 1,80o akçe, and an En'äm-ı Şerif was sold for 620 akçe (the relatively low price suggests that perhaps it was only the süra). ${ }^{35}$ In 1765 , daily wages in Istanbul were 33.7 and 50.7 akçe for a common labourer and a mason, which shows the high quality of these Daläil al-Khayrāt copies compared to most of the copies listed in Table $1 .{ }^{36}$ Even though there would have been differences due to condition and craftsmanship, Daläil al-Khayrāt copies were often cheaper than most Qur'ān copies and books on theology, but more expensive than books on geography and literature. $^{37}$

32 Şevket Pamuk, İstanbul ve Diğer Kentlerde 500 Ylllık Fiyatlar ve Ücretler 1469-1998 (Ankara: Başbakanlık Devlet İstatistik Enstitüsü, 2000), 196.

33 M. Şükrü Hanioğlu, A Brief History of the Late Ottoman Empire (Princeton, NJ: Princeton University Press, 2008), 38-41. See also Burak, "Prayers, Commentaries, and the Edification of the Ottoman Supplicant," 242.

34 Henning Sievert, "Verlorene Schätze. Bücher von Bürokraten in den Muhallefāt-Registern," in Buchkultur im Nahen Osten des 17. und 18. Jahrhunderts, eds. Tobias Heinzelmann and Henning Sievert (Bern: Peter Lang, 2010), 237-238. See also Henning Sievert, "Eavesdropping on the Pasha's Salon: Usual and Unusual Readings of an Eighteenth-Century Ottoman Bureaucrat," Osmanlı Araştırmaları/The Journal of Ottoman Studies XLI (2013): 159-195. Sievert, "Verlorene Schätze," 211-212, 239-241. For the value of silver guruş (120 akçe) in the eighteenth century, see the table in Pamuk, Osmanlı Imparatorluğu'nda Paranın Tarihi, 178.

$3_{6}$ Pamuk, İstanbul ve Diğer Kentlerde 50o Yillık Fiyatlar ve Ücretler 1469-1998, 194.

Erünsal, Osmanlılarda Sahaflık ve Sahaflar, 193-199. 


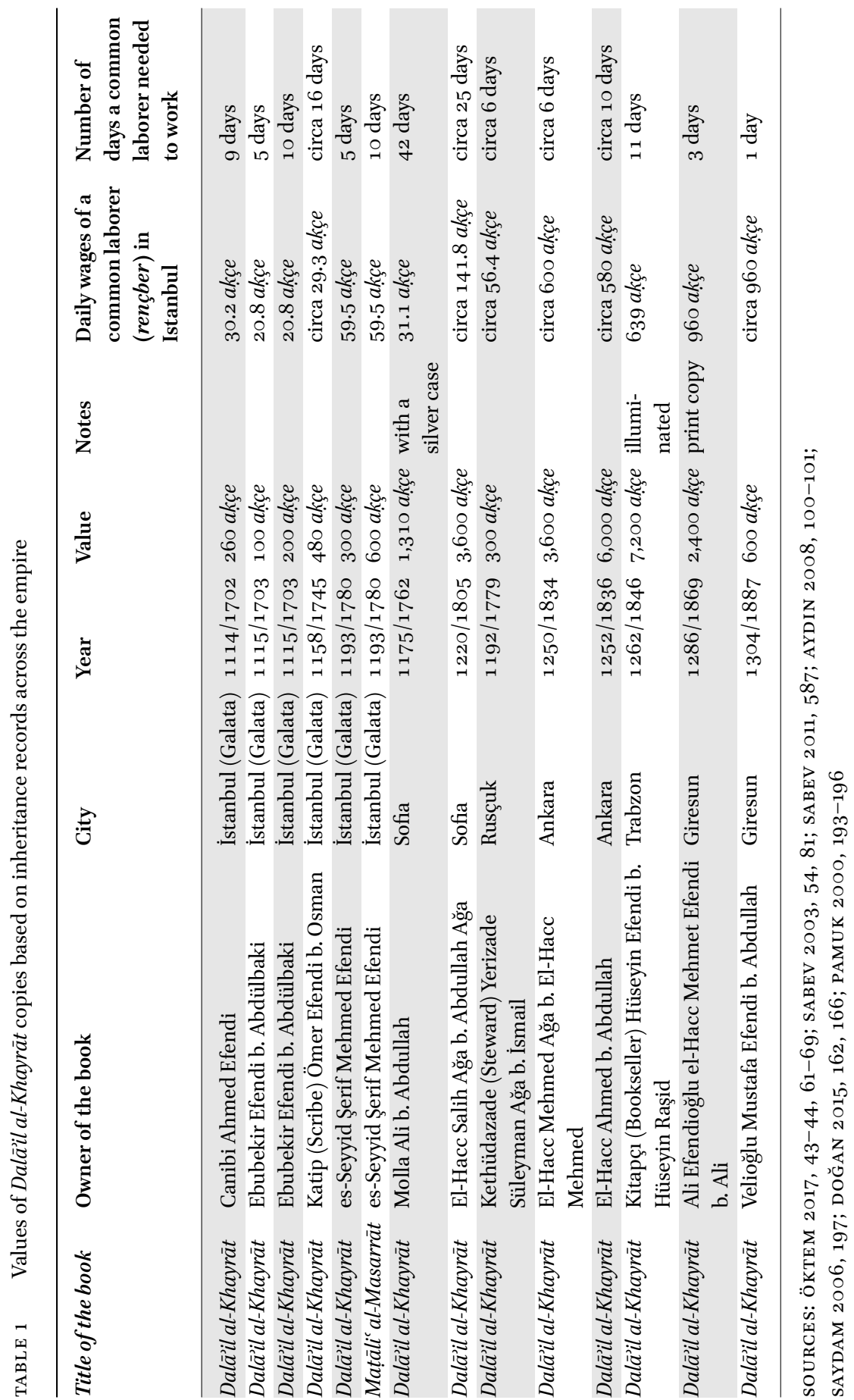


As eighteenth- and nineteenth-century inheritance records from all over the empire demonstrate, the Daläil al-Khayrät and its commentaries were commonly owned and circulated along with other books such as Yazıcıoğlu Mehmed Efendi's (d. 855/1451) Muhammediyye and 'Abd al-Wahhāb alSha'rānī's (d. 1565) al-Mīzān al-Kubrā (The Supreme Scale). From Damascus to Trabzon and from Ankara to Sarajevo, Daläil al-Khayrāt manuscripts were available in a wide range of prices, which meant they could be afforded by upper and middle classes. ${ }^{38}$ Already at the beginning of the eighteenth century, Daläil al-Khayrät copies could be found in inheritance records from Istanbul; al-Jazuli's text perhaps gradually (or simultaneously) gained popularity in other parts of the empire, such as Sofia, Rusçuk, and Giresun [table 1]. A short survey of inheritance records published in secondary sources shows that Daläil al-Khayrāt copies were purchased or commissioned in different calibres, were owned by people of various occupations, and did not necessarily become cheaper with its print production in the nineteenth century. These records only show cases taken to court and the registers that have survived and been studied. We can conclude, therefore, that the market for the Daläil al-Khayrāt must have been much much larger than what the sources suggest.

As Nelly Hanna shows based on inheritance records and 'Abd al-Raḥmān al-Jabartì's (d. 1240/1825) 'Ajāìib al-āthār fìl-tarājim wa'l-akhbār (Remarkable Remnants of Lives and Events), the Daläil al-Khayrāt was a "bestseller" in eighteenth-century Cairo. ${ }^{39}$ It was commercially produced and frequently

38 Nisa Öktem, "xvıır. Yüzyıl Galata Terekelerine Göre Osmanlı'da Kitap Kültürü” (Master's thesis, Marmara University, 2017), 43-44, 61-69; Asim Zubčević, "Book Ownership in Ottoman Sarajevo, 1707-1828" (PhD thesis, Leiden University, 2015), 182, 267; Faruk Doğan, "Bir Eğitim Tarihi Kaynağı Olarak Giresun Şer'iye Sicilleri. Tereke Kayıtlarına Yansıyan Kitaplar," Turkish Studies 10 (2015): 162, 166; Fatih Bozkurt, "Tereke Defterleri ve Osmanlı Maddi Kültüründe Değisşim (1785-1875 İstanbul Örneği)" (Master's thesis, Sakarya University, 2011), 45; İhsan Aydın, "Tanzimat Döneminde Ankara ve Gaziantep Terekelerinin Mukayeseli Bir Çalışması” (Master's thesis, Cumhuriyet University, 2008), 100-101; Nazik Betül Çelik, "Tereke Defterlerine Göre II. Mahmud Döneminde Tokat'ın Sosyal ve Ekonomik Yapısı" (Master's thesis, Gaziosmanpaşa University, 2008), 48; Abdullah Saydam, “Trabzon'da Halkın Kitap Sahibi Olma Düzeyi (1795-1846)," Milli Ĕ̈itim 170 (2006): 197; Orlin Sabev, "Okuyan Taşralı Bir Toplum. Rusçuk Müslümanlarının Kitap Sevgisi (1695-1786)," in Balkanlar'da İslām Medeniyeti Uluslararası Üçüncü Sempozyum Tebliğleri, 1-5 November 2006, Bucharest, ed. Ali Çaksu (Istanbul: IRCICA, 2011), 2.587; Sabev, "Private Book Collection in Ottoman Sofia, 1671-1833," Études Balkaniques 1 (2003): 54, 81; and Colette Establet and Jean-Paul Pascual, "Les livres des gens à Damas vers 170o," Revue des mondes musulmans et de la Méditerranée 87-88 (1999): 160, 164.

39 Nelly Hanna, In Praise of Books: A Cultural History of Cairo's Middle Class, Sixteenth to the Eighteenth Century (Syracuse, NY: Syracuse University Press, 2003), 94-96. For the popularity of the Dalāil al-Khayrāt, see also Rachida Chih, Sufism in Ottoman Egypt:Circulation, 
found in the private libraries of people from different social classes. Al-Jabarti mentions three avid copyists of the Dalāil al-Khayrāt in Cairo in their respective necrologies: Ismāîl b. 'Abd al-Rahmān (d. 1187/1774); Shaykh Ahmad (d. 1194/178o); and Ismāīl Efendi (d. 1211/1796-1797). ${ }^{40}$ If we combine this information with the references in biographical dictionaries and inheritance records, the prevalence and popularity of the Daläil al-Khayrāt in the major centres of the empire, as well as smaller Balkan and Anatolian cities, becomes clear.

\section{4}

\section{Royal Ownership}

The Daläil al-Khayrāt and other prayer books could be found in ordinary homes - as inheritance records confirm - and private spheres of the Ottoman palaces. ${ }^{41}$ Two lists in the Atatürk Library provide an insight into Pertevniyal Valide Sultan's (d. 1883), the mother of Sultan Abdülaziz (r. 1861-1876), devotional practices. These documents recorded "personal scriptures/litanies that she had read for over forty-fifty years" (ḳırk elli seneyi mütecāviz kıräàt buyurmakda oldukları evrād-i mahșușa). ${ }^{42}$ They include a copy of the Qur'ān (Hafiz Osman, 1187/1773, 13 lines); a miscellany of the Daläil al-Khayrāt and the En'ām$\iota$ Şerīf (Hafız Hasan Raşid, 1253/1837-1838, 7 lines); a copy of Mīr Sayyid 'Alī Hamadānīs (d. 786/1384) Awrād al-Fathiyya (es-Seyyid Mehmed Sadeddin Burusavi, 1278/1861-1862, 15 lines); a miscellany of the Hizb al-Bahr and alDawral-A' $\bar{l} \bar{a}$ (Abdüssamed el-Hacc Rasim Mehmed, 9 lines); and a miscellany of prayers, the Khatm al-Khwājagān (a Naqshbandi dhikr), and the Asmä' Awliy $\bar{a}^{\prime}$ ( 7 lines), as well as her prayer beads [figure 4$].^{43}$

Renewal and Authority in the Seventeenth and Eighteenth Centuries (London: Routledge, 2019), 99 .

40 'Abd al-Raḥmān al-Jabartī, 'Abd al-Rahmmān al-Jabartī's History of Egypt. 'Ajāỉb al-Āthār fìlTarājim wa'l-Akhbār, eds. Thomas Philipp and Moshe Perlmann (Stuttgart: Franz Steiner Verlag, 1994), 643-644 in vol. 1, 96 and 447 in vol. 2. See also Hanna, In Praise of Books, 95. For the recruitment of women in the Jazuliyya order, see Vincent J. Cornell's article in the present volume. For intersections of devotional practices in shrines and domestic spaces, see Jonathan Parker Allen, "Sanctifying Domestic Space and Domesticating Sacred Space: Reading Ziyarra and Tașliya in Light of the Domestic in the Early Modern Ottoman World," Religions 11/59 (2020). Available at https://doi.org/10.339o/rel11020059 last accessed 22 November $202 \mathrm{O}$.

42 Atatürk Library, PVs. Evr. 1676 (20 Ramazan 1301/14 July 1884) and PVs. Evr. 2202. The former recorded the objects in Pertevniyal Valide Sultan's tomb and her personal books, whereas the latter listed only her personal books.

43 It is not possible to securely identify these manuscripts; however, there is a Daläil al- 


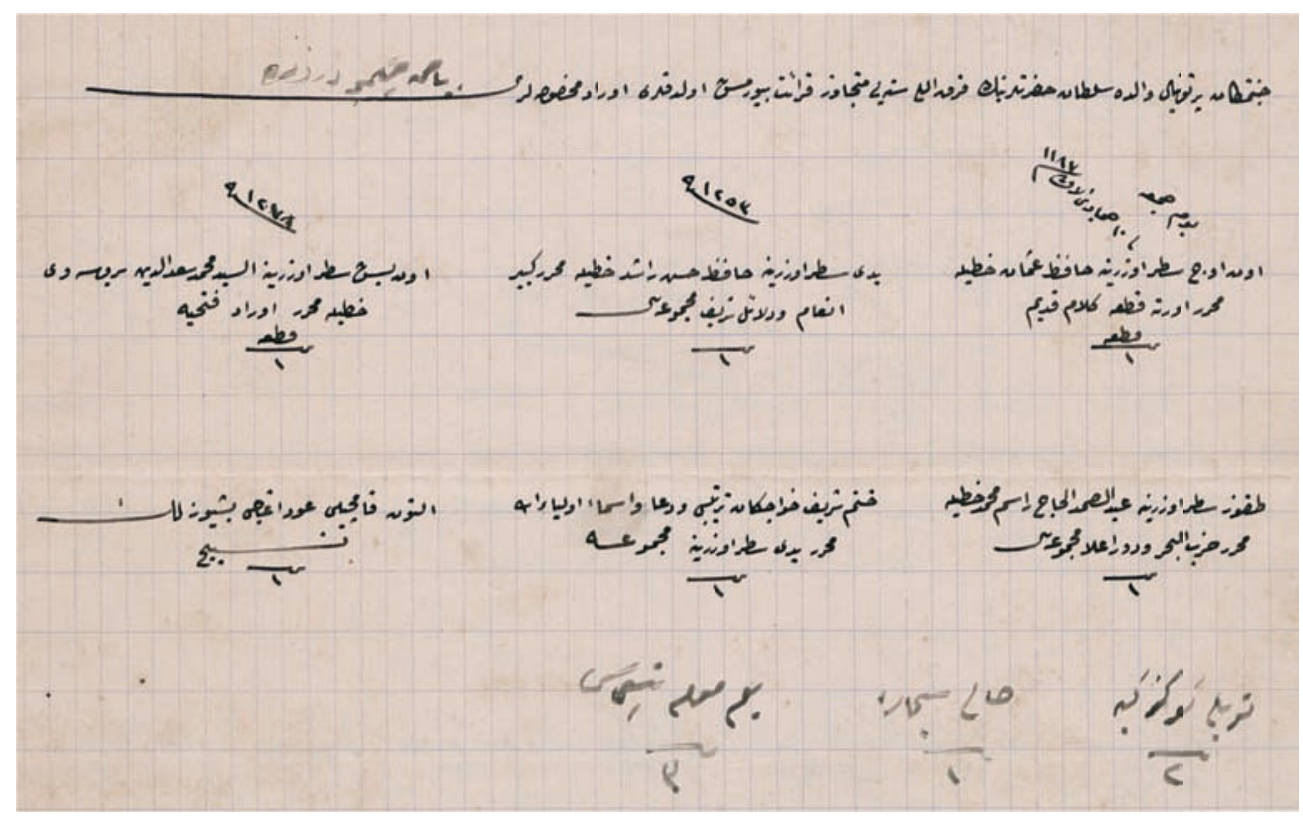

FIGURE 4 List showing Pertevniyal Valide Sultan's personal prayer books, 20 Ramazan 13O1/14 July 1884 ATATÜRK LibRARY, PVS. EVR. 1676, P. 4, DETAIL

A later document requested the placement of all these objects in the queen mother's tomb; however, as three inventories of the tomb demonstrate, not all of them were sent there. ${ }^{44}$ The Valide Sultan was known for her piety, her

Khayrāt in the Süleymaniye Library (Pertevniyal 33) and an En'ām-ı Şerîf in the Istanbul University Library (A 6386) that are close matches for the two miscellanies mentioned in the lists. For the Naqshbandi dhikr, see Reşat Öngören, "Hatm-i Hācegān," in Türkiye Diyanet Vakfı İsläm Ansiklopedisi, vol. 16 (Istanbul: Türkiye Diyanet Vakfı, 1997), 476-477. For the commentaries of the Awräd al-Fathiyya, see Burak, "Prayers, Commentaries, and the Edification of the Ottoman Supplicant," 240-241.

44 For the placement of the objects, see Atatürk Library, PVs. Evr. 855. For the inventories, see Atatürk Library, Pertevniyal Valide Sultan Evrakı (Pvs. Evr.) 3857-3859. Among these documents, PVs. Evr. 3857 is dated to 20 Ramazan 1301/14 July 1884. These lists include an En'äm-ı Şerîf and a Du'ä' Risālesi among four Qur'ān copies, one to two printed catechisms, a scroll of seven gracious verses (äyet-i kerime muharrer tomār), two printed seals/magic squares (vefk-i mühr-i şerīfler), the beard of the Prophet (lihye-i sa'ädet), and blessed objects (teberrükät-i celīle). Among the blessed objects are a piece of the golden waterspout of the Ka'ba (altun olukdan kıț a), the keys/locks to Mecca and Medina (miftāh $i$ şerîfler), the veil of 'A'isha (nikāab-i şerīf) with her name inscribed on it, the cap of Uways al-Qarani (tāc-i şerīf ), and the mantles of Hasan and Husayn (hurka-i sa'ädetler), which were kept in a box lined with silver. See also Bahar Bilgin, "The Aksaray Pertevniyal Valide 
closeness to Sufi orders, and her charitable works, which extended to Mecca, Medina, and Jerusalem..$^{45}$ The contents of her library and personal scriptures attest to her interest in devotional texts, as well as to her status, which allowed her to endow and own highly-valued items, such as the miscellany of the Awräd al-Fathiyya (Litanies of Revelations), the Dalä'il al-Khayrāt, and other awräd and prayers preserved in the Topkapi Palace Museum Library (H 93) ${ }^{46}$ This 1285/1868-1869 manuscript was copied by Mehmed Nazif and illuminated by Hasan Pertev for the queen mother. ${ }^{47}$ The compilation of these two texts and others in a single volume must have been practical for Pertevniyal Valide Sultan's silent reading or for the recitations of these texts.

There are other Ottoman royal women who had prayer books in their possessions. For instance, a miscellany including the Daläil al-Khayrät and the Hizb al-Bahr in the Topkapi Palace Museum Library (EH 1070) was dedicated to Huşyar Kadınefendi (d. 1859), a wife of Mahmud II (r. 1808-1839). ${ }^{48}$ This manuscript was copied by Mehmed Emin Rüşdi, a disciple of (Laz) Ömer Vasfi, in 1232/1816-1817 and illustrated with a dyad of al-Masjid al-Ḥarām and al-Masjid al-Nabawī. ${ }^{49}$ In Huşyar Kadınefendi's prayer miscellany, her name appears in an illuminated medallion that follows the colophon and appears to

Sultan Mosque Complex: Reflections on the Patronage of a Nineteenth Century Valide Sultan" (Master's thesis, Koç University, 2016), 98.

45 Ali Akyıldız, "Müsrif, Fakat Hayırsever. Pertevniyal Valide Sultan," The Journal of Ottoman Studies 47 (2016): 52; and Bilgin, "The Aksaray Pertevniyal Valide Sultan Mosque Complex," 50-6o.

46 Pertevniyal Valide Sultan's book endowments will be mentioned in the following section. However, here it is worth noting that she endowed a late copy of the fourth volume of the Siyer-i Nebi to the library of her building complex in Aksaray in 1279/1862-1863. This manuscript is T. 1974, preserved in the Museum of Turkish and Islamic Arts in Istanbul. Çağlarboyu Anadolu'da Kadın, 240, cat. C 77; and Zeren Tanındı, Siyer-i Nebī. İslam Tasvir Sanatında Hz. Muhammed'in Hayatı (Istanbul: Hürriyet Vakfı Yayınları, 1984), 34-35.

47 Karatay, Topkapı Sarayı Müzesi Kütüphanesi Arapça Yazmalar Kataloğu, vol. 3, 302, cat. 5616. For a short entry on the calligrapher, see İnal, Son Hattatlar, 220-223. I would like to thank Zeren Tanındı for bringing this manuscript to my attention.

48 For a short entry on Huşyar Kadınefendi, see Sakaoğlu, Bu Mülkün Kadın Sultanları, 544546; and Uluçay, Padişahların Kadınları ve Kızları, 121-123.

49 Fehmi E. Karatay, Topkapı Sarayı Müzesi Kütüphanesi Türkçe Yazmalar Kataloğu, vol. 1 (Istanbul: Topkapı Sarayı Müzesi, 1961), 134, cat. 392. For a short entry on the calligrapher, see İnal, Son Hattatlar, 337-339. For a corpus of three En'äm-ı Şerîf copies by the calligrapher, see Sabiha Göloğlu, "Depicting the Islamic Holy Sites: Mecca, Medina, and Jerusalem in Late Ottoman Illustrated Prayer Books," in Proceedings of the 15th International Congress of Turkish Art, Naples, 14-16 September 2015, eds. Michele Bernardini, Alessandro Taddei, and Michael Douglas Sheridan (Ankara: Republic of Turkey Ministry of Culture and Tourism, 2018), 323-338. 


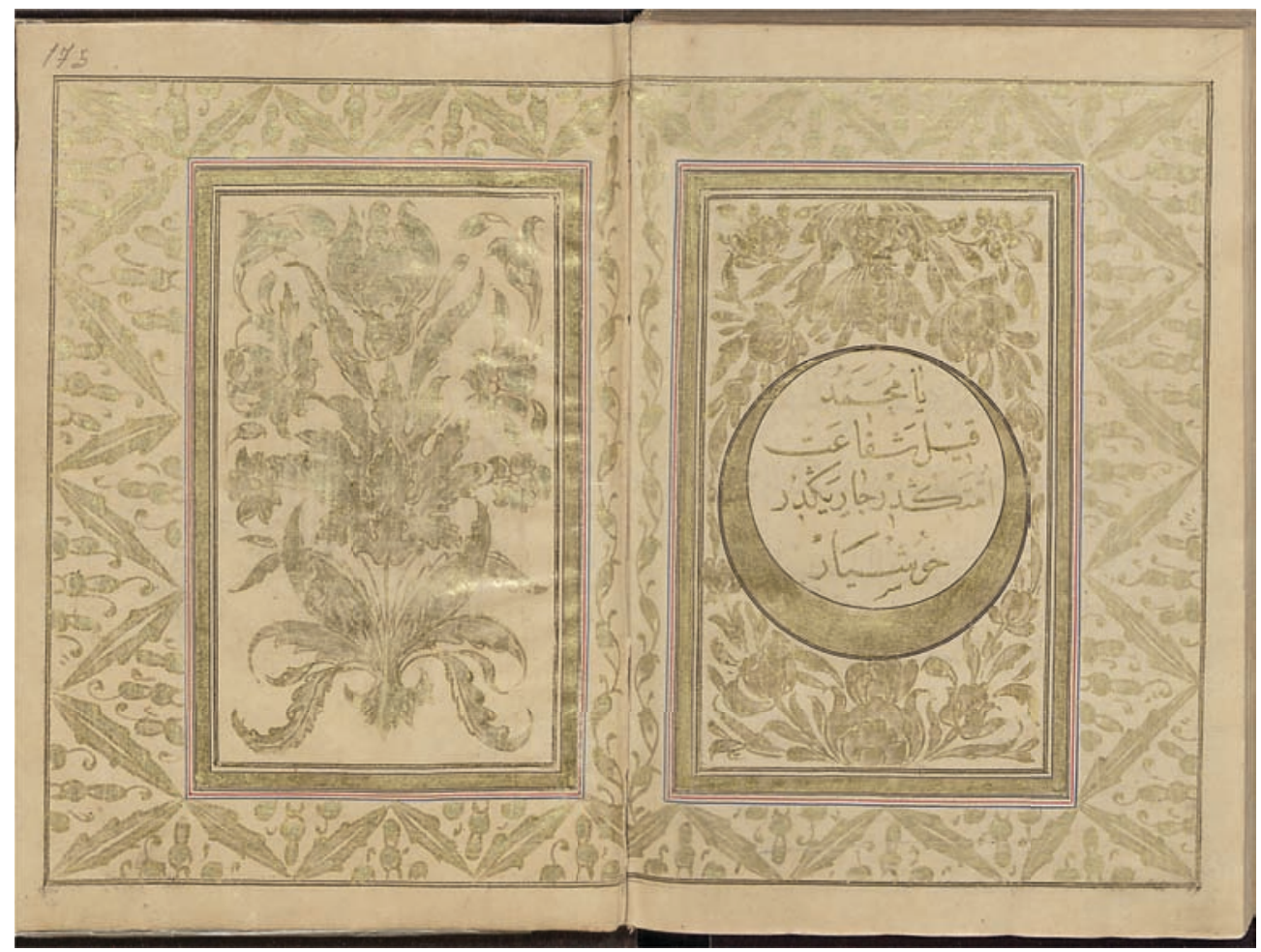

FIGURE 5 Illuminated double page with a dedication. Prayer miscellany of Huşyar Kadınefendi. Dalāंil al-Khayrāt and Hizb al-Bahrr, 1232/1816-1817, copyist: Mehmed Emin Rüşdi, 21×14 cm, 175 folios, 7 lines

TOPKAPI PALACE MUSEUM LIBRARY, EH 1070, FOLS. 174B-175A

be contemporary with the illumination [figures 5 and 6]. The golden inscription in the crescent-shaped medallion reads: "O Muhammad, intercede [on her behalf] Huşyar is your believer and your slave" (Yã Muhammed, ḳll şefā'at ümmetindir, cāriyendir Huşyār). ${ }^{50}$ The same line, but with the name "Şemsiye," appears in a red marginal inscription at the end of a miscellany of the al-Hizb al-A'zam and the Hizb al-Bahr in the Kubbealtı Foundation Ekrem Hakkı Ayverdi Collection (EHA IX/2). ${ }^{51}$ Mehmed Emin Rüşdi copied this prayer

50 According to the Hijaz yearbook of 1886, nine reciters of Qur'ān sections (sing. eczā'hān) were supported from Huşyar Kadınefendi's endowment. Selman Soydemir, Kemal Erkan, and Osman Doğan, Hicaz Vilāyet Salnamesi, H. 1303/M. 1886 (Istanbul: Çamlıca, 2008), 81.

$5^{1}$ Eryavuz, Sakin, Göloğlu, and Duran, Catalogue of the Manuscripts in the Collection of the Kubbealtı Foundation, 270-271, cat. 96. 


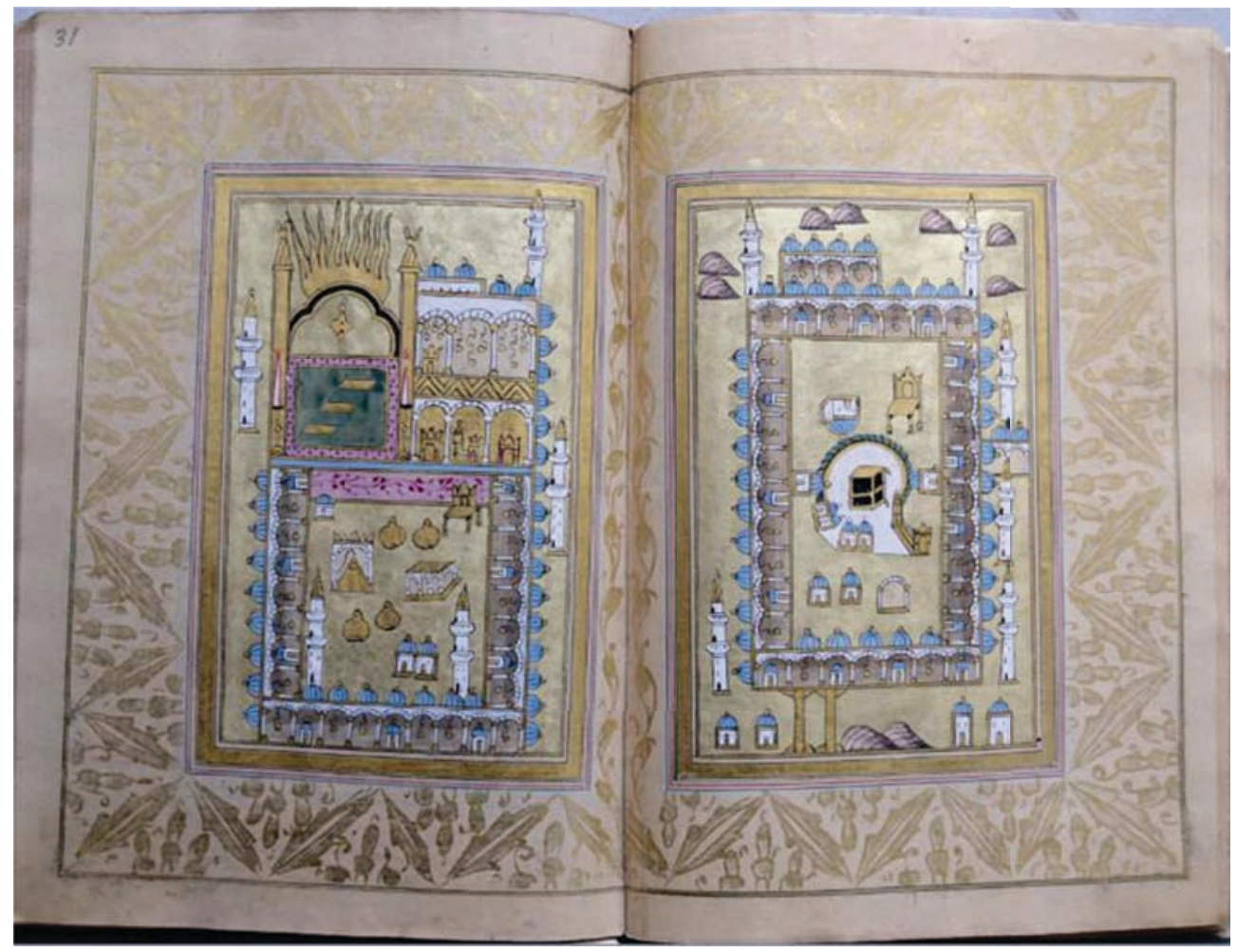

FIgURE 6 Al-Masjid al-Ḥarām and al-Masjid al-Nabawī. Prayer miscellany of Huşyar Kadınefendi. Dalāil al-Khayrāt and Hizb al-Baḥr, 1232/1816-1817, copyist: Mehmed Emin Rüşdi, $21 \times 14$ cm, 175 folios, 7 lines

TOPKAPI PALACE MUSEUM LIBRARY, EH 1O7O, FOLS. 3OB-31A

book only a year later, in 1233/1817-1818, for Huşyar Kadınefendi's head servant (başkalfa) Şemsiye. ${ }^{52}$

Atiyye Sultan (d. 1850), a daughter of Mahmud II (r. 1808-1839) and Piruzifelek Kadınefendi (d. 1863), also possessed a copy of the Dalāil al-Khayrāt, which is now held in the Museum of Turkish and Islamic Arts in Istanbul (T. 1442).53 Like those of Huşyar Kadınefendi and Şemsiye, Atiyye Sultan's prayer book was also copied by the same calligrapher, Mehmed Emin Rüşdi

$5^{2}$ Archival documents reveal that Şemsiye was the head servant of Huşyar Kadınefendi. For instance, see TS. MA.e. $5^{6} 5^{-562}$ to $5^{6} 5^{-572}$ in the Republic of Turkey's Presidency State Archives.

53 For a short entry on Atiyye Sultan, see Sakaoğlu, Bu Mülkün Kadın Sultanları, 557-559; and Uluçay, Padişahların Kadınları ve Kızları, 134-135. 
(teberdār-i serāy-i 'atīk), in 1245/1829. ${ }^{54}$ In a golden, lobed medallion preceding the colophon, the manuscript was prominently noted as belonging to the princess ('ișmetlü Ațiiyye Sultān 'aleyhi'ş-şān efendimiz hażretlerinindir).

Another royal lady who had a prayer book in her name is Düzdidil Kadın Efendi (d. 1845), ${ }^{55}$ the third wife of Sultan Abdülmecid (r. 1839-1861). Düzdidil Kadın Efendi's En'ām-ı Serîf was completed in 1261/1845 and is now held in the Bavarian State Library in Munich (Cod. Turc 553). ${ }^{56}$ It was illuminated by Hüseyin and copied by Hafiz Hasan Raşid, a disciple of es-Seyyid Mehmed Tahir Efendi. ${ }^{57}$ In the double-page colophon of this manuscript, the Enäm-ı Şerîf is described as having been written specifically for Düzdidil Kadın Efendi. As previously listed among her personal scriptures/litanies, Pertevniyal Valide Sultan also owned a miscellany of the Daläil al-Khayrāt and the En'äm-ı Şerîf by the same calligrapher, which was dated to 1253/1837-1838.

Refia Sultan (d. 188o), a daughter of Sultan Abdülmecid (r. 1839-1861) and Gülcemal Kadınefendi (d. 1851), also had an En'ām-ı Şerîf in her name, which is now held in the Collection of Ghassan I. Shaker. This manuscript was illuminated by el-Hacc Ahmed and copied by el-Hacc Mehmed Rasim, a disciple of es-Seyyid Mehmed Zakir, in 1294/1877.58 According to Nabil Safwat, Sultan Abdülmecid's name was mentioned three times in this manuscript and all written in Mehmed Rasim's hand, whereas Refia Sultan's name was mentioned twice and added later by a different hand in the areas left blank. ${ }^{59}$ Such an observation suggests that this prayer book might have been dedicated to Refia Sultan after its completion. Furthermore, the aforementioned receipt for a Dalä'il al-Khayrāt copy in Mehmed Şevket's hand confirms Refia Sultan's interest in devotional texts, whether it was for her own use or meant to be donated.

54 For the visual aspects of this manuscript, see Hüseyin Gündüz and Faruk Taşkale, EsmāünNebī. Hz. Muhammed'in İsimleri (Istanbul: Artam Antik A.Ş. Kültür Yayınları, 2018), 124127.

55 For a short entry on Düzdidil Kadın Efendi, see Sakaoğlu, Bu Mülkün Kadın Sultanları, 599; and Uluçay, Padişahların Kadınları ve Kızları, 142.

$5^{6}$ Emine Kü̧̈ükbay, "Das sogenannte Dalā’il ül-Hुayrāt. Eine Untersuchung der Handschrift [Cod. Turc. 553] der Bayerischen Staatsbibliothek, München" (Master's thesis, LudwigMaximilians-Universität München, 2010), 39-41.

57 For a short entry on Hafız Hasan Raşid, see İnal, Son Hattatlar, 300.

58 Nabil F. Safwat, Golden Pages: Qur'ans and Other Manuscripts from the Collection of Ghassan I. Shaker (Oxford: Oxford University Press for Azimuth Editions, 2000); 268-275, cat. 69. For another copy of the Daläil al-Khayrāt by Mehmed Rasim, see Pertevniyal 35 in the Süleymaniye Library. Gündüz and Taşkale, Esmä̈̈’n-Nebī, 148-151.

Safwat, Golden Pages, 268. 
Besides these royal women, there are at least two Ottoman sultans who had personal copies of the Dalä'il al-Khayrāt. In the Istanbul University Library, there are two luxury Daläil al-Khayrāt copies of palatial production that mention the names of Mahmud II and his son Abdülmecid in their colophons. A 5757 was copied by Şeyh Süleyman Vehbi el-Burusavi in 1253/1837-1838, illuminated by Ser-Mücellid es-Seyyid Mehmed Salih in 1262/1845-1846, and presented to Mahmud II. ${ }^{60}$ A 5557 , however, was copied by es-Seyyid el-Hacc Mustafa İzzet (Kadıasker), a disciple of Mustafa Vasıf, in 1258/1842-1843, upon the order of Sultan Abdülmecid. ${ }^{61}$ All these manuscripts, as well as the book and recitation endowments that will be subsequently discussed, attest to Mahmud II and his close family's interest in devotional texts. The sultan himself, his wives (Bezmialem Valide Sultan, Pertevniyal Valide Sultan, and Huşyar Kadın), his daughter (Atiyye Sultan), his son (Abdülmecid), his daughter-in-law (Düzdidil Kadın Efendi), and his granddaughter (Refia Sultan) owned and/or endowed copies of the Dalä̀il al-Khayrāt or the En'äm-ı Serîf.

Two members of the Khedival family also had a special interest in the Daläil al-Khayrāt. According to İnal, the calligrapher Arif Efendi (d. 1909) copied the Dalāil al-Khayrāt for a library in Medina and for Husayn Kāmil (r. 1914-1917), the son of Khedive Ismāill Pasha (r. 1863-1879), who later became the Sultan of Egypt under the British protectorate. ${ }^{62}$ Furthermore, Ibrāhīm Hiilmī Pasha (d. 1927), another son of Khedive Ismāill Pasha, owned a lavishly illuminated lithograph copy of the Daläil al-Khayrät with a leather binding [figure 7 ]. ${ }^{63}$ This printed copy, preserved in the Ankara Ethnography Museum (inv. no. 12075), has an illuminated lobbed medallion at the beginning of the book. ${ }^{64} \mathrm{Here}$, an inscription reveals the name of the owner as "Ibrahim Hilmi Pasha, the son of the Khedive" and provides the year $1294 / 1877-1878$, which may also correspond to the year that the illumination was completed. The colophon at the end of the book demonstrates that the calligraphy was executed by Hafiz Osman Nuri Burduri (Kayışzade) and that this edition was printed in 1293/1876 at the beginning of Murad v's short reign (r. 3o May-31 August 1876).

$60 \quad$ For a short entry on A 5757, see Yıldız Demiriz, Osmanlı Sanatında Natural Üslupta Çiçekler (Istanbul: Acar Matbaacılık Tesisleri, 1986), 232-233.

61 For a short entry on A 5557, see Ibid., 209-212.

62 İnal, Son Hattatlar, 56 .

63 For a genealogy of Khedive Ismāīl Pasha, see From the Shores of the Nile to the Bosphorus: Traces of Kavalalı Mehmed Ali Pasha Dynasty in Istanbul / Nil Kıyısından Boğaziçine. Kavalalı Mehmed Ali Paşa Hanedaninın İstanbul'daki İzleri (Istanbul: Istanbul Research Institution Publications, 2011), n.p.

64 For a short description of the copy, see Günsel Renda, "Ankara Etnografya Müzesindeki Minyatürlü Yazmalar” (Prof. diss., Hacettepe University, 1980), cat. 14. 


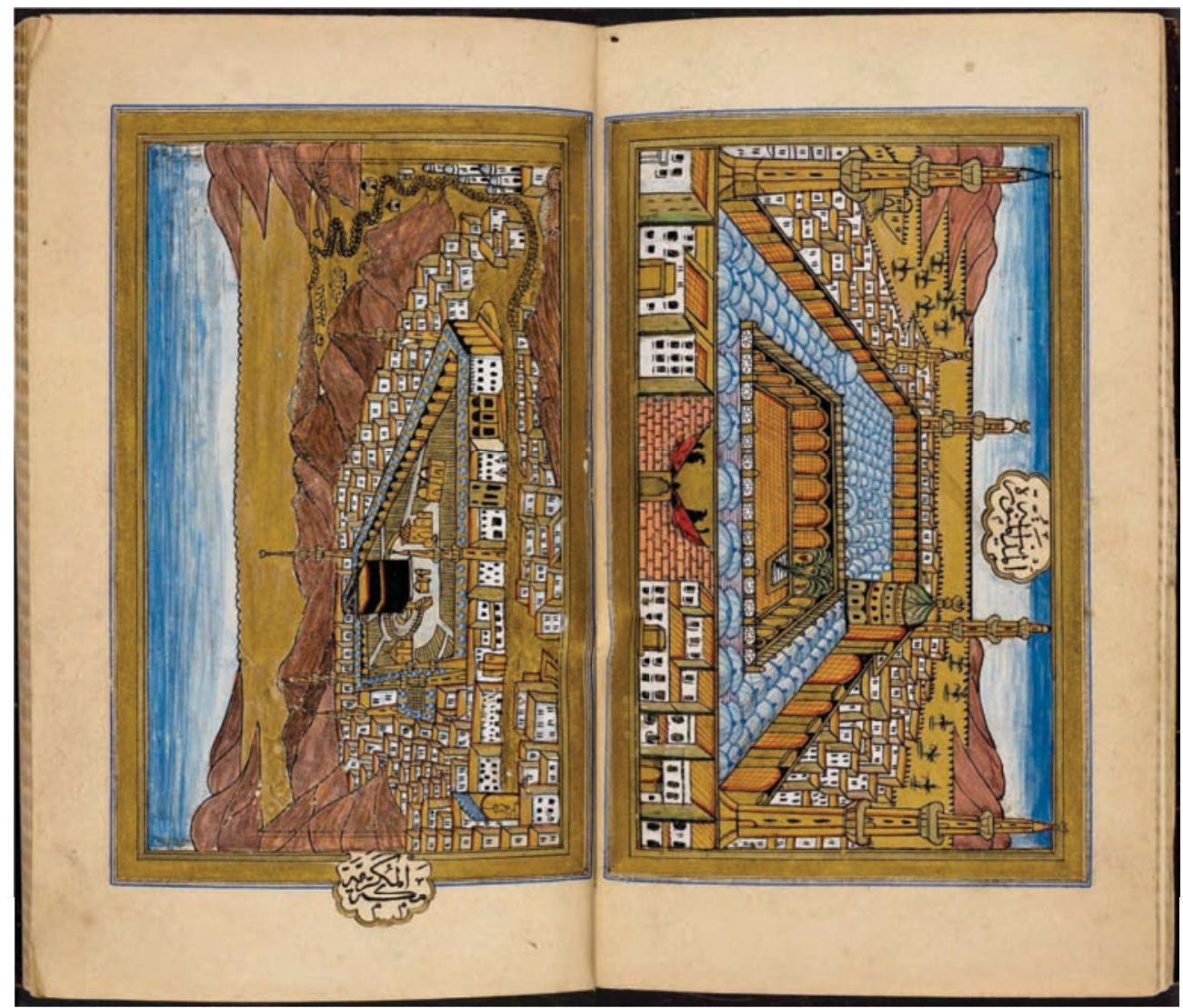

FIGURE 7 "Medīne-i Münevvere” and "Mekke-i Mükerreme." Dalāill al-Khayrāt, hand-coloured lithographic copy, printed in 1293/1876, calligrapher: Hafız Osman Nuri Burduri (Kayışzade), $16.9 \times 10.2 \mathrm{~cm}, 84$ folios, 13 lines

ANKARA ETHNOGRAPHY MUSEUM, INV. NO. 12075, FOLS. 17B-18A

Two decades later, in 1314/1896-1897, another lithograph edition of the Dalä'il al-Khayrāt in Kayışzade's hand was printed at Matbaa-i Osmaniyye with a colophon dated to $1305 / 1887-1888 .{ }^{65}$ A manuscript copy of the Daläil alKhayrāt by Kayışzade dated to $1305 / 1887-1888$ is also extant and now preserved in the Kubbealtı Foundation's Ekrem Hakkı Ayverdi Collection (EHA IX/7) ${ }^{66}$

65 For a copy from this edition, see Tahir Ağa Tekke 196M in the Süleymaniye Library in Istanbul. This copy has gold and red printed illumination and a red textile binding with gold decoration.

66 Eryavuz, Sakin, Göloğlu, and Duran, Catalogue of the Manuscripts in the Collection of the Kubbealtı Foundation, 232-235, cat. 85 . 


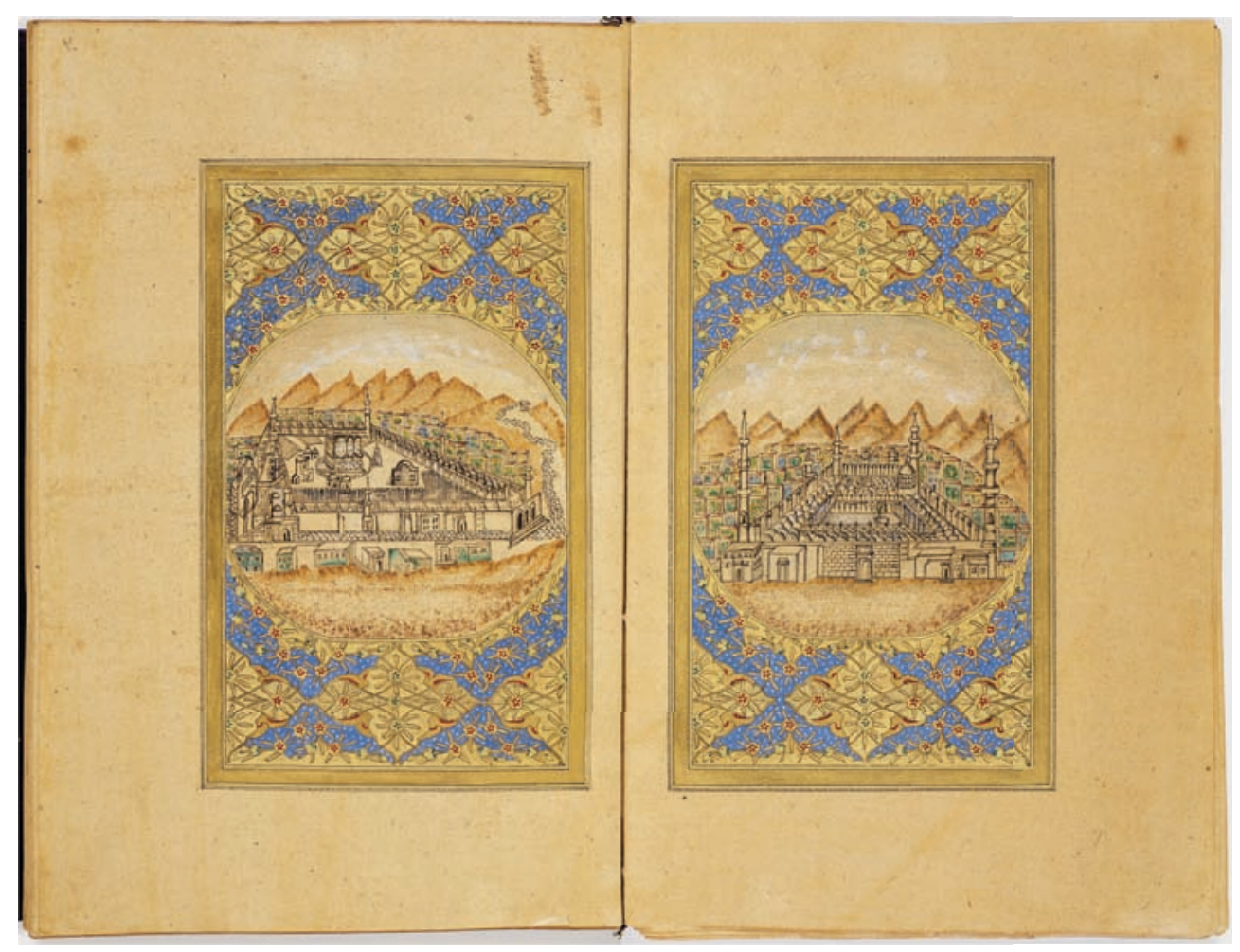

FIGURE 8 Medina and Mecca. Dalāil al-Khayrāt, 1305/1887-1888, copyist: Hafız Osman Nuri Burduri (Kayışzade), $15.9 \times 10.2 \mathrm{~cm}, 98$ folios, 11 lines KUBBEALTI FOUNDATION EKREM HAKKI AYVERDi COLLECTION, EHA IX/7, FOLS. 19B$2 O A$

The Medina and Mecca depictions in this manuscript [figure 8] and those in Ibrāhīm Hilmì Pasha's lithographic copy [figure 7] are very similar and both mirror images. They must have been drawn and printed after similar models, even though the former images are smaller and vertical, and the latter are larger and horizontal. ${ }^{67}$ In figure 8, the grisaille aesthetic of the ink drawing was maintained by only colouring the surrounding houses and hills. In figure 7 , however, the monochrome print was coloured with a thick layer of paint and gold, disguising the original lithograph. That is to say, this humble printed copy of the Daläil al-Khayrāt was carefully illuminated, painted, and bound to match the status of its prestigious owner, a son of Khedive Ismāīl Pasha. Other printed

67 For a possible connection between these depictions and the engravings of Mecca and Medina published in Ignatius Mouradgea d'Ohsson's (1740-1807) Tableau général de l'Empire othoman (1787-1820), see Göloğlu, "Depicting the Holy," 164-166. 
copies of the Dalāil al-Khayrāt with similar treatments exist. The majority of prints remained unadorned and that would gradually dominate the Ottoman production of the Daläil al-Khayrāt from the second quarter of the nineteenth century to the first quarter of the twentieth century. ${ }^{68}$

Copies of the Dalāil al-Khayrāt were held at the Ottoman palaces and in the Medina libraries, endowed to various institutions, and owned by many individuals. In the Pavilion of the Sacred Trusts (Emānāt-ı Mukaddese), or the Apartment of the Holy Mantle (Hırka-i Sa'ädet Dä'iresi), at the Topkapi Palace, prayer books could be found among the sacred trusts (emānāt), blessed objects (teberrükät), and copies and commentaries of the Qur'ān. ${ }^{69}$ The sacred trusts and blessed objects, the core of which were brought to the palace following Selim I's (r. 1512-1520) victory at the Battle of Ridaniye (1517), were kept in different parts of the Topkapi Palace, including the Privy Chamber (Hāșs Oda) that was specifically assigned for this purpose during the reign of Mahmud II (r. 18०8-1839). ${ }^{70}$ In an inventory of the Apartment of the Holy Mantle (Hırka-i Şerîf Sa'ädet-Redīf Odası) dated to 1269/1853, four Daläil al-Khayrāt were listed before and after copies of Kitāb al-Shifä and Hizb al-A'zam. ${ }^{71}$ These Dalāil al-Khayrāt copies were recorded with the following information about the copyists, endowment, and/or number of lines and volumes: Mustafa Kütahyevi (or Mustafa Kütahi, endowment of Nuri Ağa, 11 lines, 1 volume), Mehmed Hıfzı (11 lines, 1 volume), Edirneli es-Seyyid Abdullah (13 lines, 1 volume), and Veliyüddin (endowment of the calligrapher who lives in Bursa, 11 lines, 1 volume).${ }^{72}$

68 For three brief lists of nineteenth-century and early-twentieth-century printed copies of the Dalāil al-Khayrāt and Karadavudzade's commentary, see Fehmi E. Karatay, İstanbul Üniversitesi Kütüphanesi Arapça Basmalar Alfabe Kataloğu, vol. 2 (Istanbul: İstanbul Üniversitesi, 1953), 441; Karatay, İstanbul Üniversitesi Kütüphanesi Türkçe Basmalar Alfabe Kataloğu, vol. 1 (Istanbul: İstanbul Üniversitesi, 1956), 542; and M. Seyfettin Özege, Eski Harflerle Basılmış Türkçe Eserler Kataloğu, vol. 4 (Istanbul: Fatih Yayınevi Matbaası, 1977), 1645 .

69 Hilmi Aydın, The Sacred Trusts: Pavilion of the Sacred Relics (Somerset, NJ: Light, 2005), 910, 262. For changing uses of spaces in the Privy Chamber Complex, see Gülru Necipoğlu, Architecture, Ceremonial, and Power: The Topkapi Palace in the Fifteenth and Sixteenth Centuries (Cambridge, MA: The MIT Press, 1991), 141-152.

70 Aydın, The Sacred Trusts, 10.

71 The Republic of Turkey's Presidency State Archives, TS. MA.d 9oo, fol. 3a (23 Şaban 1269/1 June 1853).

These manuscripts are catalogued under "Hırḳa-i Sacādet" (in the same order as men- 
Another inventory listed the manuscripts kept in the room of the Prophet's noble standard (Sancāk-ı şerîfOdası) also in the third courtyard of the Topkapi Palace. Twenty-six copies of the Daläil al-Khayrāt, two of its commentaries, and a copy of Zayn al-Dīn al-Khwāfi's (d. 838/1435) litanies/scriptures (vird, pl. evrād) were grouped after Qur'ān and En'ām-ı Şerîf copies and before traditional prayer books (kitäb-ı ed'iye-i me'süre) and commentaries on the Qur'ān (tefāsìr-i şerîf $).{ }^{73}$ Even though these manuscripts were listed under the title "Delā'ilü'l-Hayrāt," some of them were also noted to include the al-Hizb alA'zam, the En'äm-ı Şerīf, Mevlana's (d. 672/1273) Awräd-i Kabìr (The Greater Litanies), Ḥasan al-Bașrì’s (d. 110/728) prayers for forgiveness (istig̈fär), and litanies/scriptures of day and night (evrādü'l-eyyām ve'l-leyālī). These manuscripts were numbered (except for the last six ones) and recorded with the names of their copyists or as "without colophon" (bilā ketebe) and the number of lines. ${ }^{74}$

Dalāil al-Khayrāt copies also existed in other book collections in the Topkapi Palace, including a rather late addition. In a notebook that recorded the objects that Fahreddin Paşa (d. 1948) sent from Medina to Istanbul in 1917 during World War I, several Dalāill al-Khayrāt, En'ām-ı Şerîf, al-Hizb al-A'zam, and Kitāb alShif $\bar{a}^{3}$ copies were recorded among numerous mașāhif in Medina libraries. ${ }^{75}$

tioned in the main text): HS 74 (formerly HS 351), HS 70 (formerly HS 347), HS 72 (formerly HS 349), and HS 71 (formerly HS 348). Karatay, Topkapı Sarayı Müzesi Kütüphanesi Arapça Yazmalar Kataloğu, vol. 3, 263, 270-271, cat. 5501, cat. 5466, cat. 5498, cat. 55०3.

73 The Republic of Turkey's Presidency State Archives, TS. MA.d 267, fol. ga-b. The inventory was perhaps recorded in the first half of the nineteenth century, judging by the dates of two manuscripts copied by Kebecizade Mehmed Vasfi (d. 1247/1831) in 1201/1786-1787 and 1227/1812-1813 (EH 1013 and EH 1016). This room was likely the Treasury of the Swordbearer (Silāhdār Aga Hazinesi), which was a part of the Pavilion of the Sacred Trusts or the Privy Chamber Complex. For a description of the room, see Necipoğlu, Architecture, Ceremonial, and Power, 154. See also Gülru Necipoğlu, "The Spatial Organization of Knowledge in the Ottoman Palace Library: An Encyclopaedic Collection and Its Inventory," in Treasures of Knowledge: An Inventory of the Ottoman Palace Library (1502/3-1503/4), eds. Gülru Necipoğlu, Cemal Kafadar, and Cornell H. Fleischer, Supplements to Muqarnas: Studies and Sources in Islamic Art and Architecture, vol. 1 (Leiden: Brill, 2019), 21.

74 It is possible to match some of the items in this list with the following manuscripts catalogued under "Emānet Hazīnesi": EH 1012; EH 1013; EH 1015; EH 1016; EH 1018; EH 1019; EH 1020; EH 1021; EH 1022; EH 1026; and EH 1038. Karatay, Topkapı Sarayı Müzesi Kütüphanesi Arapça Yazmalar Kataloğu, vol. 3, 264-267, cat. 5471, cat. 5472, cat. 5474, cat. 5475, cat. 5477 , cat. 5478 , cat. 5479 , cat. 548 o, cat. 5481 , cat. 5485 , cat. 5487 . I have not been able to securely match the corpus of $\mathrm{EH} 1033^{-1037}$ with the items in the list.

75 This notebook is dated to 11 Kanunusani 1335/11 January 1919 and kept in the Topkapi Palace Museum Library (YY 827). See 22b-34b for the prayer books. See also Karatay, Topkapı Sarayı Müzesi Kütüphanesi Türkçe Yazmalar Kataloğu, vol. 1, 618, cat. 1910; and Seyit Ali Kahraman, ed., Surre-i Hümāyūn (Istanbul: İstanbul Büyükşehir Belediyesi Kültür A.Ş. Yayınları, 2008), 214, 237. 
Eleven copies of the Dalāil al-Khayrāt, its two commentaries, and its two miscellanies with the al-Hizb al-Azam were transferred from the libraries of the Ravza-i Mutahhara, Mahmudiyye Madrasa, Şifa Madrasa, Hamidiyye Madrasa, and Emin Paşa to the Topkapi Palace [table 2]. ${ }^{76}$ The copyists of only nine manuscripts and the dates of five were noted in this notebook; more can be identified and matched with extant copies in a further study. ${ }^{77}$ At this point, such a record of Daläil al-Khayrāt copies in Medina libraries firmly confirms that the Prophet Muhammad was also venerated via this prayer book in the city where he was buried. ${ }^{78}$

Several endowments registered at courts list Daläil al-Khayrāt copies among the book collections bestowed to libraries, mosques, and schools. Endowments that mention the presence of this prayer book are mostly from the early eighteenth century onwards. A miscellany of al-Hizb al-A'zam and the Daläil alKhayrät and a copy of the latter were among the books that were endowed to the Fatih Mosque in Istanbul by a certain Mehmed Emin Efendi (1134/1722) and es-Seyyid Yusuf Efendi, the imam of the same mosque (1163/1750). ${ }^{79}$ Another book endowment to the Fatih Mosque (1228/1813), which included two commentaries on the Daläil al-Khayrät, was by es-Seyyid İbrahim Sarım Efendi, a minister of the Royal Mint (Darbhāne-i 'Āmire). ${ }^{80}$ With the addition of its printed copies, manuscripts of the Daläil al-Khayrāt, as well as its commentaries and miscellanies continued to feature in nineteenth-century book col-

${ }_{7} 6$ Some items in this list can be securely matched with the following manuscripts catalogued under "Medīne Kitāplı̆̆ı": M 406; M 410; M 412; M 413; and M 414. Karatay, Topkapı Sarayı Müzesi Kütüphanesi Arapça Yazmalar Kataloğu, vol. 3, 274-276, cat. 5516, cat. 5520, cat. $55^{22}$, cat. $55^{23}$, cat. $55^{24}$.

77 According to the notebook, a Daläil al-Khayrāt copy by the calligrapher and shaykh alislām Veliyüddin (d. 1182/1768) was formerly kept in the Emin Paşa Library [table 2]. Another copy of the Dalāil al-Khayrāt by Veliyüddin was kept in the Apartment of the Holy Mantle, as mentioned earlier. For the calligrapher, see Tahsin Özcan, "Veliyüddin Efendi," Türkiye Diyanet Vakfi İslām Ansiklopedisi, vol. 43 (Istanbul: Türkiye Diyanet Vakfi, 2013), 40-42.

78 For Muhammad Labīb al-Batanūn̄’s 1327/19o9 report of Qur'ān and Daläil al-Khayrāt copies donated to al-Masjid al-Nabawī, see Jan Just Witkam's article in the present volume.

79 Ayşe Buluş, "15-18. Yüzyıl Osmanlı Kütüphane Vakfiyeleri (İstanbul Kadı Sicillerine Göre Metin ve İnceleme)" (Master's thesis, Marmara University, 2019), 449-452, 510-517; and İsmail E. Erünsal, Osmanlılarda Kütüphanelerve Kütüphanecilik. Tarihi Gelişimive Organizasyonu (Istanbul: Timaş Yayınları, 2015), 188, 458.

8o Burak Delibaş, "19-2o. Yüzyll Osmanlı Kütüphane Vakfiyeleri (İstanbul Kadı Sicillerine Göre Metin ve İnceleme)" (Master's thesis, Marmara University, 2019), 126-143; and Erünsal, Osmanlılarda Kütüphanelerve Kütüphanecilik, 257. 
TABLE 2 Dalāil al-Khayrāt copies brought from the Medina libraries to the Topkapi Palace in 1917

\begin{tabular}{|c|c|c|c|c|c|}
\hline Name of the library & $\begin{array}{l}\text { Notebook } \\
\text { inv. no. }\end{array}$ & $\begin{array}{l}\text { Library } \\
\text { inv. no. }\end{array}$ & Title of the book & Copyist & Date \\
\hline Library of Ravza-i & $25^{\circ}$ & 2 & Dalāil al-Khayrāt & Hocazade Mehmed & $1177 / 1763^{-1764}$ \\
\hline Mutahhara & 251 & 6 & Dalāil al-Khayrāt & Şamizade Abdullah & $1172 / 175^{8-1759}$ \\
\hline \multirow[t]{9}{*}{$\begin{array}{l}\text { Library of the Mah- } \\
\text { mudiyye Madrasa }\end{array}$} & 276 & 43 & Dalāil al-Khayrāt & $\begin{array}{l}\text { Mehmed Şakir } \\
\text { (imam of the Kovacı } \\
\text { Dede Mosque) }\end{array}$ & $1171 / 1757-175^{8}$ \\
\hline & 278 & 48 & $\begin{array}{l}\text { Dalāil al-Khayrāt } \\
\text { and Hizb al-A'zam }\end{array}$ & Ahmed b. İsmail & \\
\hline & 279 & 49 & Dalāil al-Khayrāt & $\begin{array}{l}\text { Seyyid Mehmed } \\
\text { Şükri }\end{array}$ & \\
\hline & 301 & 9 & $\begin{array}{l}\text { Şerḥ-i Delāilü'l- } \\
\text { Hayrāt }\end{array}$ & & \\
\hline & 317 & $5^{2}$ & Dalāil al-Khayrāt & $\begin{array}{l}\text { El-Hacc Ahmed } \\
\text { Berberzade }\end{array}$ & $1179 / 17^{6} 5^{-1766}$ \\
\hline & 318 & 27 & Dalāil al-Khayrāt & & \\
\hline & 319 & 29 & Dalāil al-Khayrāt & & \\
\hline & 353 & 153 & Mațāli al-Masarrāt & & \\
\hline & 355 & 174 & Dalāil al-Khayrāt & & \\
\hline $\begin{array}{l}\text { Library of the Şifa } \\
\text { Madrasa }\end{array}$ & 657 & 49 & Dalāil al-Khayrāt & & \\
\hline \multirow{3}{*}{$\begin{array}{l}\text { Library of the } \\
\text { Hamidiyye Madrasa }\end{array}$} & 664 & 15 & Dalāil al-Khayrāt & Seyyid Ali Zühdi & $1215 / 1800-1801$ \\
\hline & & & & & \\
\hline & 665 & 84 & $\begin{array}{l}\text { Hizb al-A'zam and } \\
\text { Daläil al-Khayrāt }\end{array}$ & Hafiz Osman & \\
\hline Emin Paşa Library & 668 & 3 & Dalāil al-Khayrāt & Veliyüddin & \\
\hline
\end{tabular}

SOURCE: 1919 COPY OF THE FAHREDDIN PAŞA NOTEBOOK, TOPKAPI PALACE MUSEUM LIBRARY, YY 827 , FOLS. 22B-34B

lections. ${ }^{81}$ Al-Masjid al-Harām was also among the mosques that received book endowments; es-Seyyid Mehmed Said Paşa endowed 499 volumes to the mosque in $1289 / 1872$, among which were two printed copies of the Daläil alKhayrāt and one commentary. ${ }^{82}$

81 For three examples from Urfa, see Mehmet Kurtoğlu and Enver Karakeçili, "Urfa'da Vakıf Kitaplar Üzerine Bir Değerlendirme," Vakıflar Dergisi 43 (2015): 119-147.

82 Delibaş, "19-2o. Yüzyll Osmanlı Kütüphane Vakfiyeleri," 350-359; and Erünsal, Osmanlılarda Kütüphaneler ve Kütüphanecilik, 283. 
Several printed catalogues of Istanbul libraries also include a number of Daläil al-Khayrāt copies and its commentaries, indicating the availability of this prayer book in the major libraries of the capital in the last quarter of the nineteenth century. ${ }^{83}$ These catalogues list titles of books with a selection of the following criteria: author's name; number of volumes; language (e.g. 'Arabi and Türkì); size (e.g. șagìr and vasiț); date; copyist's name; calligraphic style (e.g. nesih and talik); number of folios; number of lines; headpiece (e.g. müzehheb and müzeyyen); ruling (e.g. müzehheb and sürh); endowment details; and print information (e.g. mațbü and țaş bașması).

In these library catalogues, Daläil al-Khayrät copies and its commentaries can be found under the section "books of hadith" (kütübül-ehādīs ), unless there are more specialized sections such as "books of prayers and special learnings" (kütüb-i ed'iye ve havāṣs ), as in the Library of Laleli Mosque. ${ }^{84}$ Some of these catalogues consist of only one commentary (e.g. the libraries of the Kıllı̧ Ali Paşa and Hekimoğlu Ali Paşa complexes while others include more than six Daläil al-Khayrāt copies (e.g. the libraries of the sultanic mosques of Laleli and Nuruosmaniyye)). The catalogue of the library of the Pertevniyal Valide Mosque has separate sections for the Daläil al-Khayrät (five copies and six commentaries) and the En'äm-ı Şerîf (five copies). ${ }^{85}$ Pertevniyal Valide Sultan's vakfiyye lists eleven Daläil al-Khayrāt among a total of 828 volumes endowed to her mosque

83 Aḳsarāy Vālide Cāmici $i$ Şerīfi Kütüphānesi Defteri (Istanbul, 1311/1893), 4-5; Defter-i Fātih Kütüphānesi (Istanbul: Maḥmūd Bey Maṭba'ası, c. 1303/1885), 44, 47-48; Defter-i Hekēmog̀lu 'Alì Paşa Kütüphānesi (Istanbul, 1311/1893), 14; Defter-i Kütüphāne-i Amuca Hüseyin Paşa (Istanbul, 1310/1892), 13; Defter-i Kütüpḩāne-i 'Aşir Efendi (Istanbul: Maḥmūd Bey Mațba'ası, 1306/1888), 13, 101; Defter-i Kütüphāne-i Āṭ̂f Efendi (Istanbul, 1310/1892), 27, 29; Defter-i Kütüphāne-iAya Șofya (Istanbul: Maḥmūd Bey Mațba'ası, 1304/1886), 35, 38; Defteri Kütüphāne-i Beşìr Aġa (Istanbul: Mațba'a-ı 'Āmire, 1303/1885), 9; Defter-i Kütüphāne-i Çelebi Abdullāh Efendi (Istanbul: 'Ātım Maṭba'ası, 1311/1893), 4-5; Defter-i Kütüphāne-i Dāmādzāde Każasker Meḥmed Murād (Istanbul, 1311/1893), 34, 37; Defter-i Kütüphāane-i Es'ad Efendi (Istanbul: Maḥmūd Bey Maṭba'ası, c. 1303/1885), 22; Defter-i Kütüphāne-i Hālet Efendi (Istanbul, 1312/1894), 7; Defter-i Kütüphāne-i Hüsrev Paşa (Istanbul: Maḥmūd Bey Mațba'ası, c. 1303/1885), 5-6; Defter-i Kütüphāne-i Lāleli (Istanbul, 1311/1893), 111, 114-115; Defter-i Kütüphāne-i Medrese-i Servīli (Istanbul: 1311/1893), 5; Defter-i Kütüphāne-i Mihrişāh Sulțān (Istanbul: Şirket-i Mürettibiyye Mațbacası, 1310/1892), 7-8; Defter-i Kütüphāne-i Nūruoșmāniyye (Istanbul: Maḥmūd Bey Maṭba'ası, 1303/1885), 47, 55; Defter-i Kütüphāne-i Rāġıb Paşa (Istanbul, 1310/1892), 18-19; Defter-i Kütüphāne-i Veliyyüddīn (Istanbul: Maḥmūd Bey Mațba'ası, 1304/1886), 32, 37; Defter-i Kütüphāne-i Yahyā Efendi (Istanbul, 1310/ 1892), 46; Hamìdiyye Kütüphānesinde Mahfüz Bulunan Kütüb-i Mevcūdenin Defteridir (Istanbul: Maṭba'a-ı 'Oșmāniyye, 130o/1882), 17; Kıılıç 'Alī Paşa Kütüphānesi Defteri (Istanbul, 1311/1893), 15; and Köprülüzāde Meḥmed Paşa Kütüphānesinde Mahfüz Kütüb-i Mevcūdenin Defteridir (Istanbul, c. 1303/1885), 19. I would like to thank Serpil Bağcı for bringing these catalogues to my attention.

84 Defter-i Kütüphāne-i Lāleli, 109.

85 Aḳsarāy Vālide Cāmi-i - Şerīfi Kütüphānesi Defteri, 4-5. 
in Aksaray (1872), which correspond to the total number of the prayer book and its commentaries in the catalogue (1893). ${ }^{86}$ Such high numbers correspond to the array of prayer books in Pertevniyal Valide Sultan's personal possession, which were addressed in the previous section.

In the endowment deed of Bezmialem Valide Sultan (d. 1853), the mother of Sultan Abdülmecid (r. 1839-1861), several prayer books were listed among the books donated to the school she founded (Dārül-Ma'ārif or Vãlide Mektebi). For instance, six Dalä̀il al-Khayrāt copies, a miscellany including the Daläil alKhayrāt, two Hizb al-A'zam copies, and a copy of Ibn al-Jazarì's (d. 833/1429) al-Hișn al-Hașin (Fortified Fortress) were listed under the title "Delāill-i Şerīf" and three commentaries of the Daläil al-Khayrāt by Karadavudzade (one print and two manuscript copies) were listed under "Hadīs Daläil al-Khayrät copies (B 1265, B 1266, B 1267, B 1268, B 1269) and the miscellany (B 1270) are identifiable and now preserved in the Beyazit Library in Istanbul. These six manuscripts carry the endowment inscriptions (1266/1849$\left.185^{\circ}\right)$ and the seal impressions (1256/1840-1841) of Bezmialem Valide Sultan. ${ }^{88}$ The inscriptions and impressions are elaborately framed and illuminated, and appear at the beginning and end of each manuscript [figure 9].

A copy defined as "Buhāāī-kār" (in the endowment deed) depicts al-Masjid al-Ḥarām and al-Masjid al-Nabawī, another one (B 1268) depicts Mecca and Medina, while another (B 1270) atypically includes a perspectival view of the Rawdia, various arrangements of the tombs of the Prophet Muhammad, Abu Bakr, and 'Umar, the seal of prophecy, a dyad of Mecca and Medina, and the hilye. ${ }^{89}$ The remaining three manuscripts (B 1265, B 1266, and B 1269) form a corpus (copied by three different calligraphers, all dated to 126o/1844-1845, and illuminated by the same hand), in which Rawdia images were uniquely replaced with those of the Prophet's belongings [figure 10]. ${ }^{90}$ Images of the

86 Bahar Yolaç-Pollock, “Ottoman Imperial Women's Contribution to the Tanzimat (18391876), The Case of Bezmialem and Pertevniyal Valide Sultans" (PhD thesis, Koç University, 2020), 37, 277. See also Bilgin, "The Aksaray Pertevniyal Valide Sultan Mosque Complex," 95-96; and Nimet Bayraktar, "İstanbul'da Kadınlar Tarafından Kurulmuş Kütüphaneler," Türk Kütüphaneciler Derneği Bülteni 12 (1963): 94.

87 Arzu Terzi, Bezmiālem Valide Sultan (Istanbul: Timaş Yayınları, 2018), 213, 219-220, 334, 336-337.

88 For various seals of Bezmialem Valide Sultan, see ibid., 119-122.

$89 \quad$ B 1267 does not have a colophon. B 1268 was copied by es-Seyyid Osman (son-in-law of İbrahim Afif) and dates to $1208 / 1793^{-1794}$. B 1270 is a miscellany of the Dalä'il al-Khayrāt, al-Hizb al-A'zam, Asmā Așhāb al-Badr, and Qașídat al-Burda. It was copied by Mahmud Raci (disciple of Mustafa Kütahi) and Ali Şükrü (disciple of Veliyüddin), illuminated by Mehmed Şevki (disciple of Kalyuni), and dates to 1191/1777-1778. 


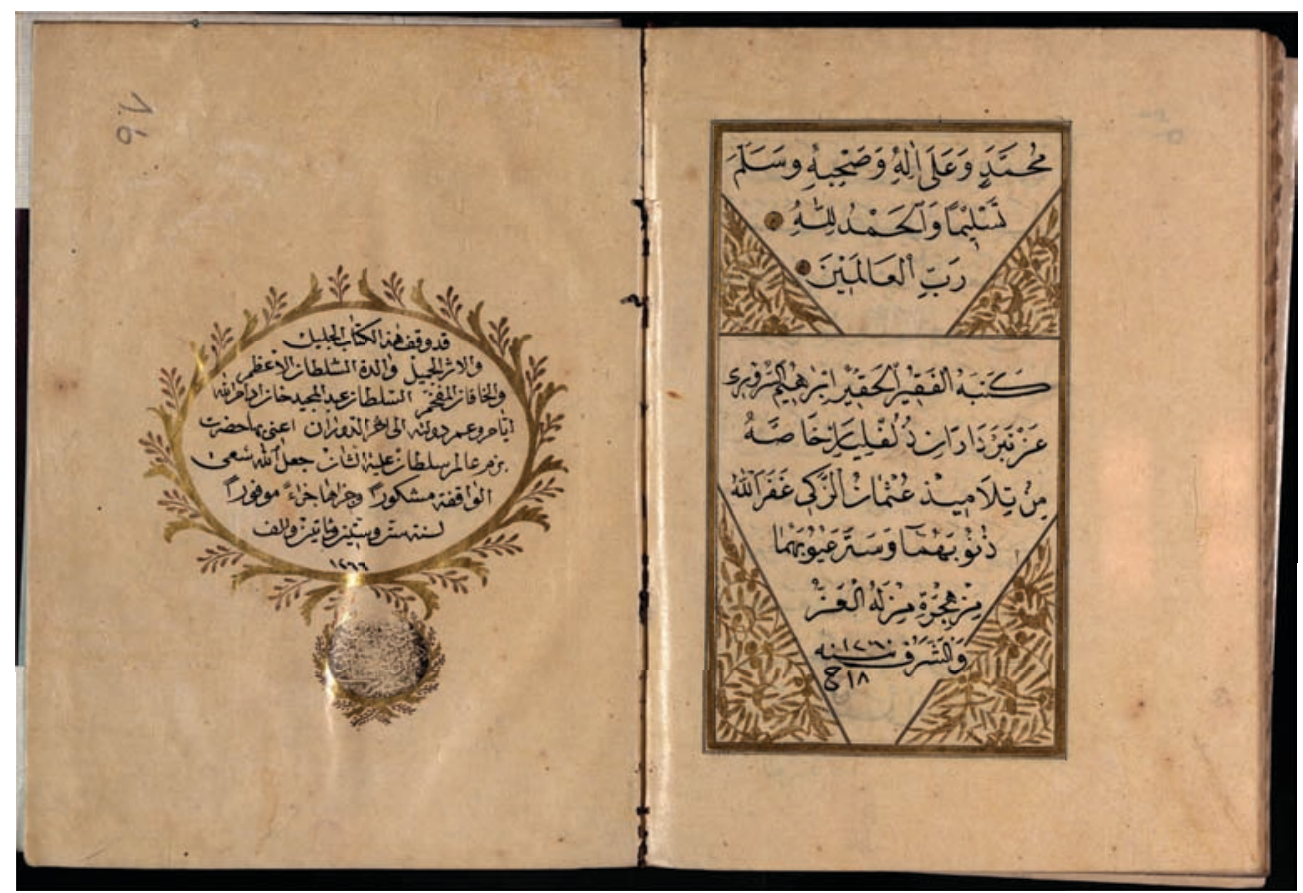

FIGURE 9 Colophon, the endowment inscriptions (1266/1849-1850), and the seal impressions (1256/ 1840-1841) of Bezmialem Valide Sultan. Dalāil al-Khayrāt, 18 Cemaziyelahir 126o/5 July 1844, copyist: İbrahim Sururi, a disciple of Osman Zeki, $22 \times 16 \mathrm{~cm}, 97$ folios, 11 lines BEYAZIT LIBRARY, B 1269, FOLS. 96B-97A

Prophet's belongings (muhallefāt) were frequently included in En'ām-ı Şerîf manuscripts and sometimes integrated into Mecca and Medina compositions of printed Daläil al-Khayrāt copies, but rarely appeared in Dalä̀il al-Khayrät manuscripts. ${ }^{91}$

Another royal woman who prominently endowed prayer books was Hatice Sultan (d. 1822), a daughter of Mustafa III (r. 1757-1774) and a sister of Selim III (r. 1789-1807). ${ }^{92}$ Hatice Sultan founded a library for the zāwiya of the Shâdhiliyya order in Unkapanı (Istanbul). It is no surprise that the fifty-five

buted to Mustafa İzzet Efendi and dates to 126o/1844-1845. Furthermore, the second item listed in the endowment deed of Bezmialem Valide Sultan is a Dalä'il al-Khayrāt copied by Mustafa İzzet, which confirms the manuscript's calligrapher. B 1266 was copied by esSeyyid Hasan Hüsni (disciple of Vasfi Efendi) and dates to 126o/1844-1845. B 1269 was copied by İbrahim Sururi and dates to 18 Cemaziyelahir 126o/5 July 1844.

91 Göloğlu, "Depicting the Islamic Holy Sites," 328-329, fig. 11-12.

92 For Hatice Sultan, see Sakaoğlu, Bu Mülkün Kadın Sultanları, 477-482. 




FIGURE 10 Belongings of the Prophet Muhammad. Dalā'il al-Khayrāt, 18 Cemaziyelahir 126o/5 July 1844, copyist: İbrahim Sururi, a disciple of Osman Zeki, $22 \times 16 \mathrm{~cm}, 97$ folios, 11 lines BEYAZIT LIBRARY, B 1269, FOLS. 12B-13A

volumes she registered at court in 1231/1816 included the order's founder alShādhilī's litanies (e.g. Hizb al-Baḥr and al-Hizb al-Kabìr) and al-Jazūlī's Dalā'il al-Khayrāt, in addition to their commentaries. ${ }^{93}$ The Daläil al-Khayrāt was frequently compiled with al-Shadhili's litanies in North African and Ottoman prayer miscellanies; therefore, the contents of Hatice Sultan's book endowment to the zawiya was more or less expected. However, it is one thing to have all these Daläil al-Khayrāt copies and miscellanies in library, madrasa, mosque, palace, and zawiya collections, it is another thing to understand their different uses.

93 Delibaş, "19-20. Yüzyll Osmanlı Kütüphane Vakfiyeleri," 144-154; and Erünsal, Osmanlılarda Kütüphanelerve Kütüphanecilik, 254-255. 


\section{Recitation and Transmission}

The Daläil al-Khayrāt could be used in various ways, including public recitation to honour the Prophet Muhammad under the benevolence of wealthy and pious patrons. Nina Ergin's work on the soundscape of sixteenth-century Istanbul mosques and Mustafa Güler's work on the sixteenth- and seventeenthcentury Haramayn endowments provide an insight into the auditory context prior to the proliferation of the Daläil al-Khayrāt in the Ottoman lands. Based on the endowment deeds (sing. vakfyye) of the Süleymaniye and Atik Valide Mosques (1577 and 1583), Ergin compiles the lists of reciters employed in each mosque and the schedules of their recitations. Among the personnel of the Süleymaniye Mosque were ten reciters of prayer blessings for the Prophet Muhammad (sing. șalavāthān) and forty-one reciters of Sūrat al-An'ām (sing. en'ämcı or en'ämhāan). ${ }^{94}$ Both Sürat al-An'ām and blessings for the Prophet were recited daily, the former being specifically assigned after each morning prayer. $^{95}$ In the smaller Atik Valide Mosque, two reciters were employed to praise the Prophet after Friday morning and night prayers. ${ }^{96}$

Based on the Haramayn endowments of Ottoman sultans, royal women, and viziers, Güler lists the duties, number, and salaries of reciters of Qur'ān sections (sing. eczā'hān) and blessings for the Prophet (sing. șalavāthān) assigned to al-Masjid al-Harām and al-Masjid al-Nabawī. ${ }^{97}$ In endowment deeds of other mosques, one can point to similar tasks that were carried out by șalavāthāns. For instance, in each of the following mosques commissioned by royal women, one person was employed to chant odes praising the Prophet (sing. na'thān): ${ }^{98}$

94 Nina Ergin, "The Soundscape of Sixteenth-Century Istanbul Mosques: Architecture and Qur'ān Recital," Journal of the Society of Architectural Historians 67 (2008): 206-208. See also Nina Ergin, "A Sound Status among the Ottoman Elite: Architectural Patrons of Sixteenth-Century Istanbul Mosques and Their Recitation Programs," in Music, Sound, and Architecture in Islam, eds. Michael Frishkopf and Federico Spinetti (Austin, TX: University of Texas Press, 2018), 37-58.

95 As Simon Rettig has noted, a copy of the En'äm-ı Şerîf could have been more suitable for the public recitation of Sürat al-An'äm, rather than an entire mușaf. Simon Rettig, "The Rise of the Encam-ı Şerif," The Freer Gallery of Art and Arthur M. Sackler Gallery, The Smithsonian National Museum of Asian Art. Available at: https:/www.youtube.com/ watch?v=KF3XSkxgI7o last accessed 22 November 2020.

96 Ergin, "The Soundscape of Sixteenth-Century Istanbul Mosques," 211.

97 Mustafa Güler, Osmanlı Devletinde Haremeyn Vakıfları (16. ve 17. Yüzyıllar) (İstanbul: Çamlica, 2011), 139-148.

98 For Ottoman royal women's presence in acoustic space, see Nina Ergin, "Ottoman Royal Women's Spaces: The Acoustic Dimension," Journal of Women's History 26 (2014): 89-111. For epigraphic and recitation programs of sixteenth-century Ottoman mosques, see Nina 
the Sultan Mosque in Manisa; the Yeni Valide Mosque in Eminönü; and a mosque in Chios (Sakız). ${ }^{99}$

The recitation of the Daläil al-Khayrāt in the Ottoman Empire fitted into such mosque soundscapes, which were defined by piety and patronage of both men and women. As Vincent Cornell and Jan Just Witkam have pointed out earlier, the Daläil al-Khayrāt, the Qașidat al-Burda, and litanies such as the Hizb al-Barr were recited out loud during Moroccan Sufi rituals. ${ }^{100}$ However, the auditory aspects of the Daläil al-Khayrät in the Ottoman Empire has not received much scholarly attention. ${ }^{101}$ In the eighteenth century, șalavāthāns and nathāns seem to have added the Dalä'il al-Khayrāt to their repertoires, based on articles specified in endowment deeds. ${ }^{102}$ For instance, the late Syeyhülislam Mehmed Esad Efendi's (d. 1176/1753) assets were posthumously endowed by his daughter Zübeyde Hanım in 1168/1755. ${ }^{103}$ A copy of Muhammad al-Mahdī al-Fāsì's commentary on the Daläil al-Khayrāt was listed among the books bestowed to the primary school (mekteb) and madrasa of the İsmail Efendi Mosque Complex in Çarşamba, Istanbul. ${ }^{104}$ Moreover, a madrasa student was requested to recite the Daläil al-Khayrät three times a month in return for 6 akçe per recitation. ${ }^{105}$ Here, it is important to point out that Dalä'il al-Khayrāt copies were not only present in madrasa libraries and could be

Ergin, "Multi-Sensorial Messages of the Divine and the Personal: Qur'an Inscriptions and Recitation in Sixteenth-Century Ottoman Mosques in Istanbul," in Calligraphy and Architecture in the Muslim World, eds. Mohammad Gharipour and İvin Cemil Schick (Edinburgh: Edinburgh University Press, 2013), 105-118.

99 Mehtap Maçal, “Osmanlı Klasik Döneminde Üç Valide Sultan Vakfiyesi Mukayesesi” (Master's thesis, Kırıkkale University, 2011), 27, 33, 4 .

100 Cornell, Realm of the Saint, 183; and Witkam, Vroomheid en activisme in een islamitisch gebedenboek, 131-132. For the recitation of the Daläil al-Khayrāt in Central and Southeast Asia, see Alexandre Papas' and Farouk Yahya's articles in the present volume.

101 For a brief mention of the recitation of the Șalāt al-Mashishīya and the Daläil al-Khayrāt in the Ottoman branch of the Shadhili order, see Ö. Tuğrul İnançer, "Rituals and Main Principles of Sufism during the Ottoman Empire," in Sufism and Sufis in the Ottoman Society: Sources, Doctrine, Rituals, Turuq, Architecture, Literature, Fine Arts, and Modernism, ed. Ahmet Yaşar Ocak (Ankara: Turkish Historical Society, 2005), 144. See also İnançer, "Şazelīlik," 141.

102 For a brief mention of daläil-khānas and salawät-khānas in Central Asia, see Fritz Meier, "The Mystic Path," in The World of Islam: Faith, People, Culture, ed. Bernard Lewis (Thames and Hudson: London, 1976), 123. See also Chih, Sufism in Ottoman Egypt, 99.

103 Buluş, "15-18. Yüzyl Osmanlı Kütüphane Vakfiyeleri," 518-531.

104 It was Şeyhülislam İsmail Efendi (d. 1725), the father of Mehmed Esad Efendi, who founded the mosque. Muhammet Nur Doğan, "Ebūishak İsmāil Efendi," in Türkiye Diyanet Vakfı İslām Ansiklopedisi, vol. 10 (Istanbul: Türkiye Diyanet Vakfi, 1994), 278-279.

105 Buluş, "15-18. Yüzyll Osmanlı Kütüphane Vakfiyeleri," 521, 524, 529. 
recited by students, ${ }^{106}$ but they were also among the inheritance records of madrasa students. ${ }^{107}$

In his endowment deed dated to $1173 / 1760$, Şeyhülislam Dürrizade Mustafa Efendi (d. 1188/1775) also allocated a budget for the recitation (tilāvet) of the Dalāil al-Khayrāt in multiple locations. ${ }^{108}$ Dürrizade Mustafa Efendi requested the daily recitation of one hizb of the Daläil al-Khayrät in the Hacegi Mustafa Rakım Efendi Mosque in Fatih (Istanbul) by three different people, with the chief $\left(r e^{\prime} \bar{\imath} s\right)$ getting 8 a kçe per day and the other two getting 6 akçe each. ${ }^{109} \mathrm{He}$ also reserved a monthly payment of 2 guruş (240 akçe) for the shaykh's daily recitation of the entire Daläil al-Khayrät at his grandfather Kazasker Abdülkadir Efendi's zawiya in Edirnekapi (Istanbul). Finally, he granted an annual salary of $12 \dot{g}$ uruş each to four residents of Medina to recite the entire Daläil alKhayrät every day, which was half the cost of the recitations performed by the chief and the shaykh in Istanbul. It was specified that the recitations should be followed by one Sūrat al-Fātiḥa and three Sūrat al-Ikhlāṣ, all for the merit $(\underline{s} e v \bar{a} b)$ of the waqf. ${ }^{110}$ As the highest ranking figure in the Ottoman learned class ('ulemā), the endowment deed of this important religious leader (şeyhü̈lislām or shaykhal-islām) indicates the permissibility of the Daläillal-Khayrät in the political and spiritual centres of the Ottoman Empire in the mid-eighteenth century. Its embracement by Ottoman 'ulema $\bar{a}$ is in stark contrast with the teachings of Ibn 'Abd al-Wahhāb (d. 1206/1792), who disapproved of the veneration of the prophets and saints, the visitation of their tombs and shrines, and the recitation of texts such as the Daläil al-Khayrāt. ${ }^{111}$

106 In the grand vizier Halil Hamid Paşa's (d. 1785) endowment deed dated to 1198/1784, two commentaries of the Daläil al-Khayrāt and al-Hizb al-A'zam were noted among the 106 manuscripts bestowed to the Çeşmecizade Madrasa in Burdur. Olivier Bouquet, "Pour une histoire instrumentale des savoirs ottomans. À quoi servaient 'livres tenus en haute estime' et autres précieux manuscrits conservés dans une bibliothèque de madrasa anatolienne (Burdur, seconde moitié du Xvinie siècle)?" Arabica 67 (2020): 567-568, fig. 2.

107 Bilgin Aydın and İsmail E. Erünsal, "Tereke Kayıtlarına Göre Osmanlı Medrese Talebelerinin Okuduğu Kitaplar (XVı-Xx. Yüzylllar)," in Osmanlı Kültür Tarihinin Bilinmeyenleri (Istanbul: Timaş Yayınları, 2019), 185.

108 Murat Erten, "Dürrizāde Mustafa Efendi Vakfiyesi" (Master's thesis, Selçuk University, 2007), 12-16, 31-32, 62-64.

109 In 176o, a carpenter's (neccār) daily wage was 62.2 akçe and a common labourer's (rençber) was 33.7 akçe. Pamuk, Osmanlı İmparatorluğu'nda Paranın Tarihi, 194.

110 Erten, "Dürrizāde Mustafa Efendi Vakfiyesi," 12-16, 31-32, 62-64.

111 Eyüp Sabri Paşa, Tarih-i Vehhābyan, trans. Süleyman Çelik (İstanbul: Bedir Yayınevi, 1992), 64-65; Mehmet Ali Büyükkara, "Vehhābīlik," in Türkiye Diyanet Vakfı İslām Ansiklopedisi, vol. 42 (İstanbul: Türkiye Diyanet Vakfi, 2012), 611-615; and Betül Ayaz, "Hilafet ve Siyaset. Osmanlı Devleti'nin Hac Hizmetleri (1798-1876)" (PhD diss., Marmara University, 2014), 71. 
Another recitation example from the same period comes from Aleppo. ${ }^{112}$ In his endowment deed dated to $1177 / 1763$, al-Haàjj Mūsā al-Amīrī, a wealthy dignitary of the city, designated the recitation of this popular text in his mosque. ${ }^{113}$ Almost a century later, an official report hints at the continuous presence of the Daläil al-Khayrät in the soundscape of the city. ${ }^{114}$ This document (1274/1858) approved the increase of Shaykh Ma'rūf Efendi's monthly salary from 10o gंuruş to 250 guruş for reciting the Daläil al-Khayrāt and Sürat al-Kahf at the Great Mosque of Aleppo every Friday. ${ }^{115}$

As Şeyhülislam Dürrizade Mustafa Efendi's endowment deed (1173/176o) and a number of nineteenth-century documents point out, the Daläil alKhayrāt also had an auditory prevalence in the Haramayn. Based on the endowment deed of Bezmialem Valide Sultan (d. 1853), Bahar Yolaç-Pollock has noted that the valide sultan donated three Dalāill al-Khayrāt copies and one En'äm$\iota$ Şerîf copy to al-Masjid al-Nabawī and commissioned three deläilhāns for the former's daily recitation in 1257/1841 (each person reciting one hizb a day). ${ }^{116}$ In a report dated to $1273 / 1857$, the annual sum (6,ooo giuruş) that Bezmialem Valide Sultan endowed for the deläilhāns was recorded among gifts and allowances sent to the Haramayn (șurre). ${ }^{117}$ A payroll dated to ${ }_{126} / 1847$ further documents salaries funded from Mahmud II's (r. 1808-1839) endowments, which were paid to the teachers (müderrisin) and students (țalebe) of the Ḥanafì, Shāfi'ì, and Mālikī schools, as well as other employees (hademe) respon-

112 Several other documents in the Republic of Turkey's Presidency State Archives relate to the public recitation of the Dalä'il al-Khayrāt. For instance, C..EV.. 244-12155 is about the funds allocated for the recitation of the Daläil al-Khayrāt at Fatih Mosque, which was disputed by Şeyh Ahmed Nebih Efendi after his father el-Hacc Ali b. Hüseyin's death. C..EV.. 46-2267 is about the disputes that arose after the death of a trustee (el-Hacc Mustafa Ağa), who was running an endowment made to the Hatice Valide Sultan Mosque in the name of an underaged descendant (Mehmed Ruhi b. Mehmed Sadık). I would like to thank Nazlı Vatansever for helping me read these two documents.

113 Jihane Tate, Une waqfiyya du XVIIIe siècle à Alep. La waqfiyya d'al Häăğğ Mūsā al-Amìrī (Damascus: Institut français de Damas, 199o), 115, [87]. Available at https://www.doabooks .org/doab?func=search\&query=rid:40115 last accessed 22 November 2020. See also Hanna, In Praise of Books, 95 .

114 The Republic of Turkey's Presidency State Archives, İ..MVL. 392-17104 (29 Şaban 1274/ 14 April 1858).

115 In 1857, in Aleppo, a carpenter's (neccār) daily wage was 1,644 akçe and a labourer's (ırgat) was 540 akçe. Pamuk, Osmanlı Imparatorluğu'nda Paranın Tarihi, 204.

116 Yolaç-Pollock, "Ottoman Imperial Women's Contribution to the Tanzimat (1839-1876)," 70-71. See also Terzi, Bezmiālem Valide Sultan, 198.

117 The Republic of Turkey's Presidency State Archives, Ev.d.. 16317 (11 Receb 1273/7 March 1857). See also Mustafa Budak et al., eds., Osmanlı Belgelerinde Surre Alayları (Ankara: T.C. Başbakanlık Devlet Arşivleri Genel Müdürlüğü, 2010), 45. 
sible for reciting Qurāan chapters (sing. sūrehāan), Muhammad al-Bukhārī's (d. 256/870) collection of hadīths, the Kitäb al-Shifä, and the Daläil al-Khayrät (sing. deläilhān) at al-Ḥaram al-Sharîf (more likely al-Masjid al-Ḥarām or alMasjid al-Nabawī rather than the Temple Mount). ${ }^{118}$ Only two years later, in a document dated to $1265 / 1849$, a teacher of the Daläil al-Khayrät named Melik Paşazade Şeyh Ali Efendi is listed as one of the former recipients of the șurre. ${ }^{119}$ Together, these two documents show that al-Jazuli's renowned text was not only recited, but also taught in the Haramayn. ${ }^{120}$

In addition to the recitation of the Daläil al-Khayrāt in religious spaces, Karadavudzade's Turkish commentary was also read out loud in late Ottoman reading groups (meclis, pl. mecālis). ${ }^{121}$ Süleyman Çelebi's (d. 825/1452) Mevlid$i$ Şerîf (Noble Birth), the fourteenth-century poet Mustafa Darir's Siyer-i Nebi (Life of the Prophet), Yazıcıoğlu's Muhammediyye, and catechisms were among the other religious texts that were read out loud. ${ }^{122}$ Certificates (sing. ijäza or icāzet) of teaching, transmission, hearing, and reading/recitation found in Daläil al-Khayrät copies and its commentaries also attest to the auditory and public use of this prayer book and its commentaries. ${ }^{123}$ At the end of a copy of Muhạammad ibn Ismāīl al-Rayḥānī al-Rūmī’s commentary Muntij al-Barakāt 'alā Dalāil al-Khayrāt (Isl. Ms. 525), held in the University of Michigan Library (Special Collections Library), one can find a very fitting example [figure 11]. This manuscript's copyist es-Seyyid Nuh b. es-Seyyid Mehmed Kuriçay was authorized by Ömer b. Mustafa Erzincani (his seal impression follows at the end) for

118 The Republic of Turkey's Presidency State Archives, Ev.d.. 32282 (25 Zilhicce 1263/4 December 1847).

119 The Republic of Turkey's Presidency State Archives, Ev. HMK. SR, 3926. See also Ayaz, "Hilafet ve Siyaset," 26o-262.

120 According to the Hijaz yearbook of 1886, the Sufi lodge (zāwiya) of the Jazuliyya order was located in the Kuşaşiyye quarter of Mecca at the northeast of al-Masjid al-Harām. Soydemir, Erkan, and Osman Doğan, Hicaz Vilāyet Salnamesi, 81.

121 Zehra Öztürk, "Osmanlı Döneminde Kıraat Meclislerinde Okunan Halk Kitapları," Türkiye Araştırmaları Literatür Dergisi 9 (2007): 421-423.

122 Ibid., 405.

123 For more information on certificates, see İrvin Cemil Schick, "İslāmī Kitap San'atlarında Standartlaşma. Usta-Çırak İlişkisi ve İcazet Geleneği," The Journal of Ottoman Studies 49 (2017): 231-266; Mohammad Ali Karimzadeh Tabrizi, Ijazatnameh-Icāzetname: The Most Unique and Precious Document in Ottoman Calligraphy, trans. Telli Karimzadeh Tabrizi (London: Published by the author, 1999); Jan Just Witkam, "The Human Element between Text and Reader: The Ijaza in Arabic Manuscripts," in The Codicology of Islamic Manuscripts, ed. Yasin Dutton (London: Al-Furqān Islamic Heritage Foundation, 1995), 123-136; and M. Uğur Derman, "Türk Yazı San'atında İcazetnāmeler ve Taklid Yazılar," in VII. Türk Tarih Kongresi, Ankara, 25-29 Eylül197o (Ankara:Türk Tarih Kurumu, 1972), 2.716728 . 


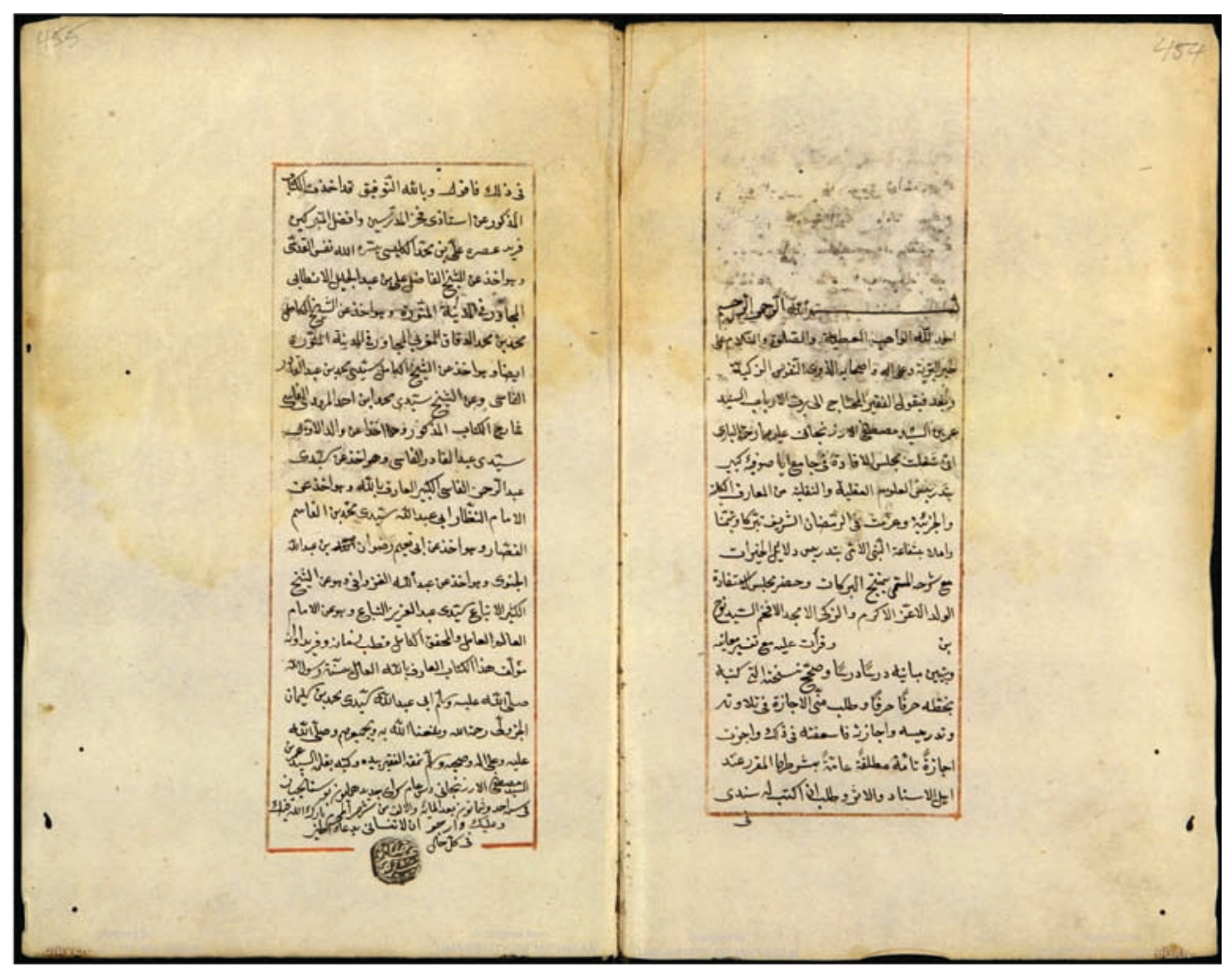

FIGURE 11 Recitation, teaching, and transmission certificate given to the copyist es-Seyyid-Seyyid Nuh b. es-Seyyid Mehmed of Kuruçay (Erzurum) by es-Seyyid Ömer b. es-Seyyid Mustafa on 1 Muharram 1181/3o May 1767. Muntij al-Barakāt 'alā Dalāil al-Khayrāt, 11 Shawwāl 118o/12 March 1767, $21.7 \times 15.5 \mathrm{~cm}, 23$ o folios, 23 lines UNIVERSITY OF MICHIGAN LIBRARY, SPECIAL COLLECTIONS RESEARCH CENTER, ISL. MS. 525 , PP. $454-455$

the recitation (tilāvet), teaching (tedrīs), and transmission (icāzet) of the text in $1181 / 1767$, shortly after the completion of the copying. ${ }^{124}$

Several other ijāzas added to Dalä̉il al-Khayrāt copies or miscellanies exist. In a particularly interesting manuscript of al-Hizb al-A'zam and the Dalāil alKhayrāt in the Kubbealtı Foundation Ekrem Hakkı Ayverdi Collection (EHA VII/7), one can find two ijāzas for recitation (ǩıräat) given to Hacı Mustafa by Hafiz Süleyman el-Erzurumi at the end of the respective texts (1170/

124 For a description of this manuscript, see Evyn Kropf's detailed entry at "Muntij al-barakāt 'alá Dalāil al-khayrāt," Mirlyn Catalogue. Available at http://mirlyn-classic.lib.umich.edu: 80/F/?func=direct\&doc_number=006782183\&local_base=AA_PUB last accessed 22 November 2020. 
1756-1757) and one later ijāza of Daläil al-Khayrāt recitation given to İsmail Hakkı Paşa by el-Kadiri el-Nakşibendi el-Hacc Mustafa at the end of the manuscript (1240/1824). ${ }^{125}$ The regional spread and temporal continuation of the Dalāil al-Khayrāt in written and auditory spheres owed as much to such authorized transmissions and public recitations as it did to simply copying and reading the text.

\section{7}

\section{Conclusion}

The high demand for the Daläil al-Khayrāt in the late Ottoman Empire required its production in manuscript form in large numbers, printing the text in several editions, and bestowing copies to mosques and libraries. The Daläil al-Khayrāt was copied and read among Sufi circles; however, the text's popularity cannot be solely explained via its links to specific religious orders. Ottoman sultans, royal women, members of the Khedival family, the learned, and wealthy individuals also had a special interest in this devotional text. They used the Daläil al-Khayrāt as private prayer books and some of them displayed their benevolence via book and recitation endowments. The availability of the Daläil al-Khayrāt in public (both in writing and in sound) must have increased its prevalence among the larger community, as there are extant copies of different calibres, from luxurious to modest.

With the help of a wide range of Dalā'il al-Khayrāt copies and archival documents, it has been possible to sketch a societal realm within which this devotional text was produced, traded, read, and recited during the late Ottoman period. The multiplication of manuscript and print examples, the surfacing of new documents, the handling of different sources, and the reinterpretation of the same materials will certainly yield other aspects of the Daläil al-Khayrāt in the future. Nevertheless, at this stage of the scholarship, the late Ottoman context for the Daläil al-Khayrāt can be elaborated, to a certain extent, in terms of its commercial production, widespread circulation, diverse ownership, institutional endowment, and public recitation.

125 Eryavuz, Sakin, Göloğlu, and Duran, Catalogue of the Manuscripts in the Collection of the Kubbealtı Foundation, 244-247, cat. 88. 
Conspectus of Manuscripts, Archival Documents and a Few Printed Books

No place mentioned, Collection of Ghassan I. Shaker

Cat. No. 69

Ankara, Atatürk Library

PVs. Evr. 1676

PVS. Evr. 2202

PVS. Evr. 3857

PVs. Evr. 3858

PVS. Evr. 3859

Ankara, Ankara Etnografya Museum 12075

Ann Arbor, University of Michigan

Library, Special Collections Research

Center

Isl. Ms. $5^{25}$

Berlin, Staatsbibliothek

Or. 14194

Bursa, İnebey Manuscript Library

HO 1223

HO 1224

HO 1225

HO 1226

HO 1227

Istanbul, Beyazit Library

B 1265

B 1266

B 1267

B 1268

B 1269

Veliyyüddin 567

Veliyyüddin 568
Istanbul, Istanbul University Library

A 1663

A 5557

A 5559

A 5584

A 5721

A 5757

A 6386

Istanbul, Kubbealtı Foundation, Ekrem

Hakkı Ayverdi Collection

$$
\begin{aligned}
& \text { EHA VII } / 4 \\
& \text { EHA VII } / 7 \\
& \text { EHA IX/2 } \\
& \text { EHA IX } / 7
\end{aligned}
$$

Istanbul, Museum of Turkish and Islamic Arts

T. 1442

T. 1974

Istanbul, The Republic of Turkey's Presidency State Archives

C..EV.. 46-2267

C..EV.. 244-12155

D.M.d, 37228

Ev.d.. 16317

Ev.d.. 32282

Ev. HMK. SR, 3926

İ..MVL. 392-17104

TS. MA.d 267

TS. MA.d 900

TS. MA.e 9-17

TS. MA.e. $5^{6} 5^{-62-565^{-72}}$

Istanbul, Sadberk Hanım Museum

SHM Küt. 611 
Istanbul, Sakıp Sabancı Museum

103-0359

Istanbul, Süleymaniye Library

Pertevniyal 33

Pertevniyal 35

Tahir Ağa Tekke 196M

Istanbul, Topkapi Palace Museum

Library

EH 1012

EH 1013

EH 1015

EH 1016

EH 1018

EH 1019

EH 1020

EH 1021

EH 1022

EH 1026

EH 1033

EH 1038

EH 1070

EH 1334
EH 1335

EH 1336

EH 1337

H 93

HS 70 (formerly HS 347)

HS 71 (formerly HS 348)

HS 72 (formerly HS 349)

HS 74 (formerly HS 351)

M 406

M 410

$\mathrm{M}_{412}$

M 413

M 414

YY 827

Konya, Mevlana Museum

İhtisas Kütüphanesi 5917

Müze 45

London, British Library

Or. 7259

München, Bayerische Staatsbibliothek

Cod. Turc. 553 